\title{
Protein intake from 0 to 18 years of age and its relation to health: a systematic literature review for the 5th Nordic Nutrition Recommendations
}

\author{
Agneta Hörnell'*, Hanna Lagström², Britt Lande ${ }^{3}$ and \\ Inga Thorsdottir ${ }^{4}$
}

'Department of Food and Nutrition, Umeå University, Umeå, Sweden; ${ }^{2}$ Turku Institute for Child and Youth Research, University of Turku, Turku, Finland; ${ }^{3}$ Division of Public Health, Norwegian Directorate of Health, Oslo, Norway; ${ }^{4}$ Unit for Nutrition Research, School of Health Sciences, University of Iceland and Landspitali National University Hospital, Reykjavik, Iceland

\section{Abstract}

The present systematic literature review is a part of the 5th revision of the Nordic Nutrition Recommendations. The aim was to assess the health effects of different levels of protein intake in infancy and childhood in a Nordic setting. The initial literature search resulted in 435 abstracts, and 219 papers were identified as potentially relevant. Full paper selection resulted in 37 quality-assessed papers (4A, 30B, and 3C). A complementary search found four additional papers (all graded B). The evidence was classified as convincing, probable, limited-suggestive, and limited-inconclusive. Higher protein intake in infancy and early childhood is convincingly associated with increased growth and higher body mass index in childhood. The first 2 years of life is likely most sensitive to high protein intake. Protein intake between $15 \mathrm{E} \%$ and $20 \mathrm{E} \%$ in early childhood has been associated with an increased risk of being overweight later in life, but the exact level of protein intake above which there is an increased risk for being overweight later in life is yet to be established. Increased intake of animal protein in childhood is probably related to earlier puberty. There was limited-suggestive evidence that intake of animal protein, especially from dairy, has a stronger association with growth than vegetable protein. The evidence was limited-suggestive for a positive association between total protein intake and bone mineral content and/or other bone variables in childhood and adolescence. Regarding other outcomes, there were too few published studies to enable any conclusions. In conclusion, the intake of protein among children in the Nordic countries is high and may contribute to increased risk of later obesity. The upper level of a healthy intake is yet to be firmly established. In the meantime, we suggest a mean intake of $15 \mathrm{E} \%$ as an upper limit of recommended intake at 12 months, as a higher intake may contribute to increased risk for later obesity.

Keywords: BMI; bone health; growth; overweight; puberty

To access the appendices to this article please see Supplementary files under Article Tools online

Received: II February 2013; Revised: 21 March 2013; Accepted: 10 April 2013; Published: 23 May 2013

B oth quality and quantity of protein intake in infancy and childhood are of interest with regard to later risk of non-communicable diseases (NCDs) (1). In the Nordic setting, the quantity of protein intake is of utmost importance, as its quality rarely is a problem. The hypothesis that high protein in infants' diet stimulates growth and concurrently increases the likelihood of overweight and obesity later in life was first proposed in 1995 by Rolland-Cachera et al. (2). Several Nordic studies have since confirmed this association (3-5). The growth association has been thought to depend on the stimulating effect of high protein intake on insulin-like growth factor 1 (sIGF-I), which in turn may result in more rapid growth and increased muscle mass as well as fat mass (2, 6-9).

Rapid growth during the first year of life has been associated with an increased risk of overweight and obesity later in life in several epidemiological studies (7-9). Infants who are breastfed during the first 
months of life grow at a slower rate in infancy than those that are bottle-fed $(10,11)$. It has been postulated that part of the explanation is related to higher protein content of infant formula compared with mother's milk (12).

Other adverse health outcomes of high protein intake early in life have also been suggested. A systematic literature review (SLR) was needed to improve the knowledge about possible negative effects of a high protein intake. This is essential to enable formulating advice about appropriate foods to give infants and young children during the transition from breast milk to family foods, as well as for deciding safe levels for the composition of infant formulas and follow-on formulas. Further, it is important to explore the association between older children's protein intake and health.

According to the World Health Organization/Food and Agriculture Organization (WHO/FAO), reference values for protein intake is $0.9 \mathrm{~g} / \mathrm{kg} / \mathrm{day}$ from 3 to 18 years of age for boys and from 3 to 15 years of age for girls (24). Between 15 and 18 years of age, the level decreases slightly for girls to $0.8 \mathrm{~g} / \mathrm{kg} /$ day. Combining this reference value with the reference values for energy intake for age and sex, this equates to about 5 protein energy percentage $(\mathrm{PE} \%)$ at three years of age gradually increasing to about 7-9 $\mathrm{PE} \%$ at 17 years of age for boys and girls, respectively. The intake of protein in the Nordic countries is, as in many industrialized countries, more than sufficient to meet physiological requirements among children (Table 1).

In 2010, the Nordic Council of Ministers launched a project aimed at reviewing the scientific basis of the Nordic Nutrition Recommendations (NNR) issued in 2004 (25) and where necessary update a 5th edition. The NNR5 project is mainly focused on a revision of those areas in which new scientific knowledge with special relevance for the Nordic setting has emerged since the 4th edition. A number of systematic literature reviews (SLRs) will form the basis for the update.

The present SLR is focused on protein intake in infancy and childhood and the association with several different health outcomes.

\section{Aims}

The overall aim was to review recent scientific data on the short- and long-term health effects of different levels of protein intake in infancy and childhood, in order to appraise the present recommendations in a Nordic setting.

\section{Research/key questions}

1) What are the effects of different intakes and different sources of protein (animal- or plant-based) in infancy and childhood, while considering other energy-giving nutrients at the same time, on functional or clinical outcomes, including growth and development?

2) What are the effects of different intakes and different sources of protein (animal- or plant-based) in infancy and childhood, while considering other energy-giving nutrients at the same time, on wellestablished markers or indicators of functional or clinical outcomes, such as serum lipids, glucose and insulin, blood pressure, body weight, body composi-

Table 1. Protein intake among children in the Nordic countries (percent of total energy, mean values given for boys/girls, or total)

\begin{tabular}{|c|c|c|c|c|c|c|c|c|c|}
\hline & 12 months & 2 years & 4 years & 6 years & 8 years & 9 years & 10 years & II years & 13 years \\
\hline Denmark $^{1-2}$ & & $11.6 / 12.4$ & & & 13.4/- & & & & \\
\hline Finland ${ }^{3-4}$ & $15 / 16$ & $16 / 17$ & $15 / 15$ & $16 / 15$ & & & $16.1 / 16.1$ & & \\
\hline Iceland $d^{5-6}$ & $15.6 / 14.8$ & & & $15.7 / 15.0$ & & & & & \\
\hline Norway ${ }^{7-10}$ & $13.1 / 13.0$ & $|4.6 /| 4.9$ & $|4.2 /| 4 . \mid$ & & & $14.5 / \mid 4.0$ & & & $|4.8 /| 4.2$ \\
\hline Sweden ${ }^{11-12}$ & $12.7 / 12.9$ & & $14.4 / 14.4$ & & $15.4 / 15.4$ & & & $15.9 / 15.4$ & \\
\hline
\end{tabular}

\footnotetext{
'Children aged 2.5 years (13).

${ }^{2}$ Boys aged 8 years (14).

${ }^{3}$ Children aged I-6 years were born in 2003 (12 months), 200 I-2002 (2 years), 1999-2000 (4 years) (I5).

${ }^{4}$ Children aged 10 years (16).

${ }^{5}$ Children aged I year (17).

${ }^{6}$ Children aged 6 years (national data) (18).

${ }^{7}$ Children aged I year, breastfed infants not included (national data) (19).

${ }^{8}$ Children aged 2 years (national data) (20).

${ }^{9}$ Children aged 4 years (national data) (2I).

${ }^{10}$ Children aged 9 and 13 years (national data) (22).

${ }^{11}$ Children aged I year (4).

${ }^{12}$ Children aged 4,7 , and II years (national data) (23).
} 
tion, and bone mineral density, in childhood, adolescence, and adulthood?

Limits: Published since January 2000, human subjects. See below for inclusion and exclusion criteria and Appendix 1 for search terms.

\section{Methods}

\section{Search terms}

The main protein group in the NNR5-project managed the search and defined search terms in collaboration with the Infant and Young Child group and Hege Sletsjøe, librarian at the Norwegian Directorate of Health, Oslo, Norway. The search terms are presented in Appendix 1.

\section{Inclusion and exclusion criteria}

The group focused on protein intake among healthy children. Inclusion criteria in the abstract screening process were the following: English or Nordic language, study population relevant to the Nordic countries.

Papers were excluded if they focused on premature or sick children, if the study population was deemed too different from a Nordic population, if intake data was not measured in childhood, if the outcome did not match the research questions, or if the paper was a general overview rather than an SLR.

\section{Search results}

The search was run in January 2011, including all relevant population groups and clinical outcomes. The main protein group did a first scan of the abstracts and sent all abstracts relevant for the age group $0-18$ years $(n=435)$ to our group (Fig. 1). Abstract screening was conducted in February-March 2011 according to the guide for conducting SLRs for the 5th edition of the NNR (26).

A total of 219 full papers were ordered, of which 182 papers were immediately excluded (most were excluded because they did not include the research questions or were general overviews rather than SLRs), leaving 37 papers selected for quality assessment ( 8 clinical trials, 19 cohort studies, and 10 cross-sectional studies). Reasons for exclusion are provided in Appendix 2.

A complementary search was performed in February 2012 covering the time since the first search until the end of December 2011. The abstracts were similarly evaluated for full paper reading. Included complementary papers
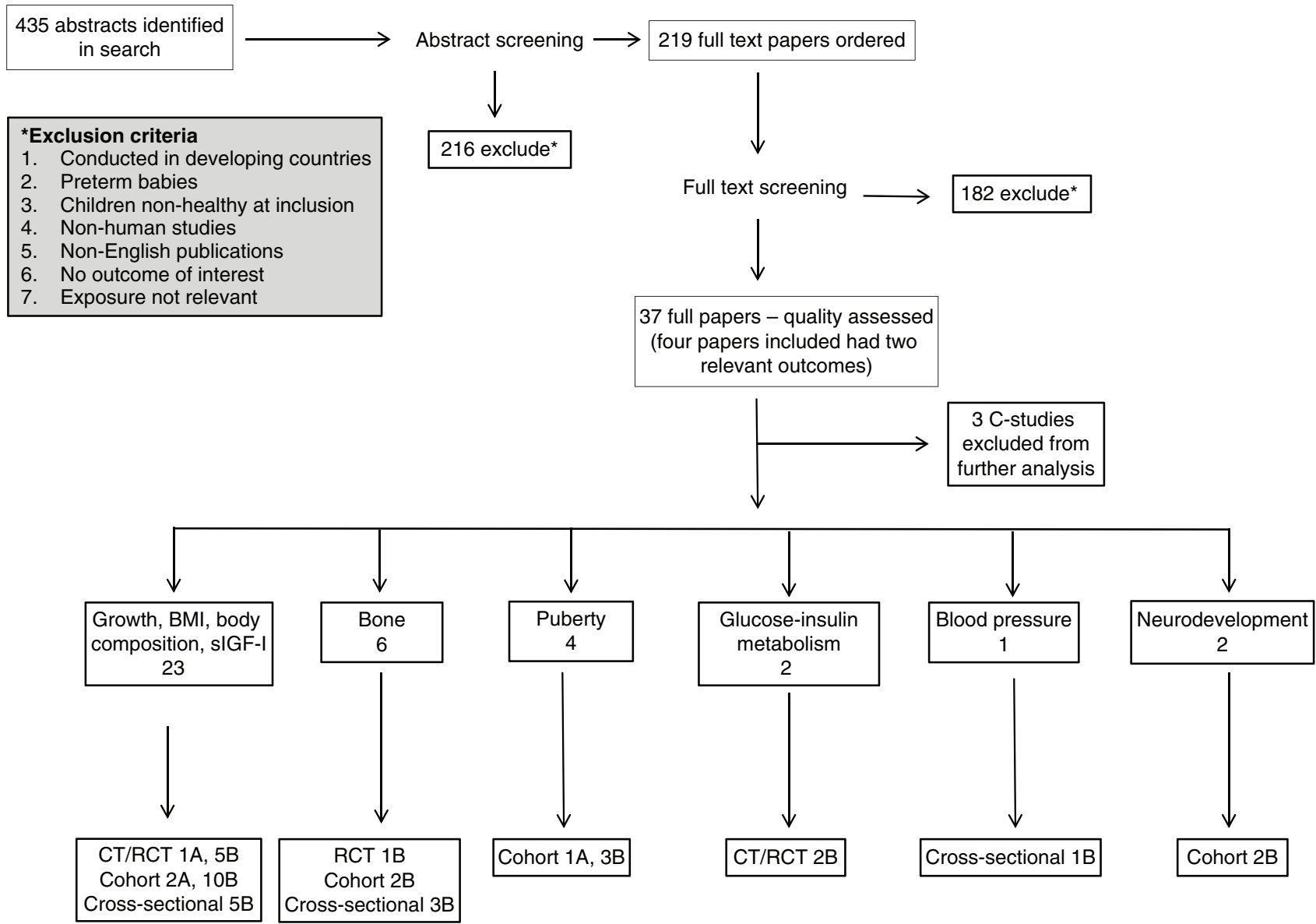

Fig. 1. Overview search results of SLR on protein intake in childhood and health outcomes 
were quality assessed and used to evaluate the conclusion of the SLR, as supporting or not.

\section{Quality assessment, grading, and reporting of evidence}

The 37 included papers were quality assessed using the quality assessment tools (QAT) received from the NNR5 secretariat (26). These contained a number of questions regarding several methodological aspects of the studies, including questions about, for example, study design, population characteristics, exposure and outcome measures, dietary assessment, and confounders.

The quality assessment resulted in the following grading - clinical trials: $1 \mathrm{~A}, 6 \mathrm{~B}, 1 \mathrm{C}$; prospective cohort studies: 3A, 16B, cross-sectional studies: 8B, 2C. Detailed information about all graded studies, divided by outcomes, is found in Appendices 3-8. Four papers had two separate outcomes.

The findings for each separate outcome are presented in Tables 2-8. Only the 34 studies graded A and B are included in these tables and used in the final grading of evidence.

All steps in the process of selecting and grading papers, that is, abstract screening, paper screening, and quality assessment, were performed as described in the guide for conducting SLRs (26). This meant that two experts evaluated each abstract/paper. The experts first made an individual appraisal, which was then discussed and a joint conclusion was decided upon.

The grade of evidence was classified as convincing (grade 1), probable (grade 2), limited-suggestive (grade 3 ), and limited-inconclusive (grade 4) depending on the number and quality of supporting, non-supporting, and contradicting studies.

\section{Results}

The majority of studies (23/34) on protein intake in infancy and childhood had different aspects of growth and body weight as outcomes (Table 2). Only a few studies focused on puberty, blood pressure, and neurodevelopment making the evidence very weak for any conclusions. When papers originated from the same research group, it was not always possible to tell whether or not the participating children were the same in several studies. This is problematic as evidence grading requires evidence from at least two independent cohort studies, or at least five case-control studies. We have taken this into account in our grading.

\section{BMI, growth, body composition, and sIGF-I}

Tables 2-3 show summaries of studies with outcome BMI, growth, body composition, and sIGF-I (details about the studies are provided in Appendix 3). In total, 23 papers were chosen in the systematic review process to be evaluated for the evidence of an association between protein intake and these outcomes. Sixteen of those include outcomes on $\mathrm{BMI} /$ growth and these are briefly described in Table 2, in addition to the more detailed descriptions given in Table 3 and Appendix 3 for all the 23 studies. Of these studies, 6 were clinical trials (1A, 5B), 12 were prospective cohort studies $(2 \mathrm{~A}, 10 \mathrm{~B})$, and 5 were cross-sectional studies (all B). One additional crosssectional study graded $\mathrm{C}$ was excluded.

Clinical trials

Hoppe et al. (27), graded B, examined in a doubleblinded randomized trial $(n=59)$ the effects of the two major milk fractions, whey and casein, and milk minerals, calcium (Ca) and phosphorus (P), on sIGF-I and glucose-insulin metabolism (see results in "Glucoseinsulin metabolism"). Eight-year-old boys were randomized to receive $540 \mathrm{ml}$ of milk-based drinks for 7 days, either: 1) whey with low mineral content ( $\mathrm{Ca}$ and $\mathrm{P}$ ); 2) whey with high mineral content; 3) casein with low mineral content; and 4) casein with high mineral content. The amount of other milk components aimed to be identical to the content in $1.5 \mathrm{~L}$ of skimmed milk.

Dietary intake was assessed using two repeated 3-day weighed food records ( 2 weekdays and 1 weekend day); the first kept before the intervention (days -3 to 0 ) and the second at the end of the intervention (days 5 to 7 ). Measurement errors in the dietary recordings were not considered, but the importance of maintaining usual dietary intake was emphasized to the families. Unintentionally, there were significant differences between the intervention groups with regard to several of the anthropometrical measurements, energy and milk intake. No interactions between milk mineral groups (high, low) and milk protein groups (whey, casein) were found, so the milk protein groups were combined.

Average daily protein intake was increased by $17 \%$ by the whey drink, from $58 \mathrm{~g} /$ day $(2.23 \mathrm{~g} / \mathrm{kg} /$ day, $13.0 \mathrm{PE} \%)$ to $68 \mathrm{~g} /$ day $(2.56 \mathrm{~g} / \mathrm{kg} /$ day, $15.4 \mathrm{PE} \%)$, and by $51 \%$ by the casein drink, from $68 \mathrm{~g} /$ day $(2.30 \mathrm{~g} / \mathrm{kg} /$ day, $14.3 \mathrm{PE} \%)$ to $103 \mathrm{~g} /$ day $(3.44 \mathrm{~g} / \mathrm{kg} /$ day, $23.4 \mathrm{PE} \%)$. In the whey group, there was no change in sIGF-I. No independent effects of a high milk mineral intake on sIGF-I were found. Increase in serum urea nitrogen (SUN), a marker for protein intake, and the molar ratio of sIGF-I/sIGFBP-3 was significantly higher in the casein group than in the whey group.

A limitation of the study, also mentioned by the authors, is that the subjects were allowed to eat their habitual diet, so there might be other factors in the diet contributing to the findings. However, the authors point out that this has been controlled for in the analyses. The results were not changed markedly after controlling for energy intake, protein intake, SUN, or milk intake. The authors conclude that casein stimulates circulating sIGF-I and that both milk protein fractions seem to be 
Table 2. Outcome growth/BMI: comparison of protein intake levels and outcome

Papers seeing a positive association between protein intake and growth, and/or BMI

\begin{tabular}{lll}
\hline Author, year & Low intake & High intake \\
(ref no.) & mean $\pm S D$ & mean $\pm S D$
\end{tabular}

or

Study design median (25th-75th median (25th-75th

(study name if applicable) percentiles) percentiles)

Age food

Effect

Age weight/

0-12 months (monthly) Boys in the highest quartile of protein intake 6 year

Gunnarsdottir 2003, Mean for group (E\%):

(3) $15 \pm 4$ at 9 months,

nationwide longitudinal $16 \pm 3$ at 12 months

Iceland

(E\%) at the age of 9-12 months had significantly

higher BMI $\left(17.8 \pm 2.4 \mathrm{~kg} / \mathrm{m}^{2}\right)$ at 6 years than

the lowest $\left(15.6 \pm 1.0 \mathrm{~kg} / \mathrm{m}^{2}\right.$,

$P=0.039)$ and the second lowest $(15.3 \pm 0.8$

$\mathrm{kg} / \mathrm{m}^{2}$,

$p=0.01$ ) quartile.

Günther,

2007

(34)

Germany

Cohort study

DONALD

Median at 18-24 months

$\mathrm{E} \%$

I3.3 (II.8-|4.7)

$\mathrm{g} / \mathrm{kg} /$ day

$2,6(2.3-3.0)$

Median at 18-24

months

E\% I3.8 (12.9-15.2)

$\mathrm{g} / \mathrm{kg} /$ day

$2.6(2.4-3.0)$
Günther,

2007

(35)

Germany

Cohort study

DONALD
Median for group at 12 months:

$\mathrm{E} \%$

I3.3 (II.7-|4.8)

$\mathrm{g} / \mathrm{kg} /$ day

$2.7(2.4-3.2)$
$6,12,18-24$ months

3-day weighed records

Consistently high protein intake 12, 18-24 7 year months positively related to increased BMI SDS

and \%BF

at 7 years;

BMI SDS $0.37(95 \% \mathrm{Cl} 0.12 .0 .6 \mathrm{I})$ vs. 0.08

$(-0.09,0.26), p=0.04$

\%BF I8.37 (I7.29, I.5I) vs. I6.9I (I6.19,I7.66),

$P=0.01$

OR for BMI > 75th percentile 2.39 (I.14, 4.99),

$P=0.02$

OR for \%BF $>75$ th percentile

2.28 (I.06,4.88), $p=0.03$.

$6,12,18-24$ months, Animal protein intake at 12 months positively 7 year

3-4 years, $5-6$ years assoc $\mathrm{w} \% \mathrm{BF}[\mathrm{mean} /$ tertil $[95 \% \mathrm{Cl})$

3-day weighed records TI; I6.2(I5.23,I7-25), T2; 17.2I(I6.24, I8.23),

T3; 18.2I(17.12, 19.15), $p=0.008$

Animal protein $\mathrm{E} \%$ at 12 months positive

association to $\mathrm{BMI}$ a 7 year $(p=0.02)$

Dairy E\% at 12 months, but not meat or cereal,

positive association to $\mathrm{BMI}$ a 7 year $(p=0.02)$

and $\% \mathrm{BF}$ at 7 year $(p=0.07)$.
Together, weight gain at $0-12$ months and protein intake at

9-12 months explained $50 \%$

of the variance in BMI among 6-year-old boys. 
Table 2 (Continued)

Papers seeing a positive association between protein intake and growth, and/or BMI

\begin{tabular}{|c|c|c|c|c|c|c|}
\hline $\begin{array}{l}\text { Author, year } \\
\text { (ref no.) } \\
\text { Country } \\
\text { Study design } \\
\text { (study name if applicable) }\end{array}$ & $\begin{array}{c}\text { Low intake } \\
\text { mean } \pm S D \\
\text { or } \\
\text { median (25th-75th } \\
\text { percentiles) }\end{array}$ & $\begin{array}{c}\text { High intake } \\
\text { mean } \pm S D \\
\text { or } \\
\text { median ( } 25 \text { th-75th } \\
\text { percentiles) }\end{array}$ & Age food & Effect & $\begin{array}{c}\text { Age weight/ } \\
\text { BMI }\end{array}$ & Comment \\
\hline $\begin{array}{l}\text { Hoppe, } 2004 \text { (36) } \\
\text { Denmark Cohort } \\
\text { (observational) }\end{array}$ & $\begin{array}{l}\text { Median for boys at } 12 \text { months } \\
\text { E\%:I4 (9-18) } \\
\text { g/kg/day: } 2.7(1.6-3.9) \\
\text { Median for girls at } 12 \text { months: } \\
\text { E\%:I3 (9-17) } \\
\text { g/kg/day: } 2.8(1.8-3.6)\end{array}$ & & $\begin{array}{l}9 \text { months: } 5 \text { days' } \\
\text { weighed food records } \\
10 \text { year: } 7 \text { days' food } \\
\text { record }\end{array}$ & $\begin{array}{l}\text { Effect estimates (linear regression) between } \\
\text { protein intake } 9 \text { months and body composition } \\
\text { (BMI and \%BF) at } 10 \text { years: } \\
\text { Protein } \mathrm{E} \% \text { at } 9 \text { months was a predictor for } \\
\text { weight at } 10 \text { years: } 0.44(0.12-0.76), P=0.007 \text {, } \\
\text { and height } 0.5 \mathrm{I} \\
(0.13-0.90), P=0.009 \text {. } \\
\text { Protein intake ( } g / \text { day - but not } g / \mathrm{kg} / \text { day) was a } \\
\text { predictor for weight, } 0.16(0.037-0.29), P= \\
0.03 \text {. }\end{array}$ & 10 year & \\
\hline $\begin{array}{l}\text { Hoppe, } 2004 \text { (I3) } \\
\text { Denmark } \\
\text { Cross-sectional }\end{array}$ & $\begin{array}{l}\text { I0th percentile } \\
2.4 \mathrm{~g} / \mathrm{kg} / \text { day } \\
50 \text { th percentile } 2.9 \mathrm{~g} / \mathrm{kg} / \text { day }\end{array}$ & $\begin{array}{l}\text { 90th percentile } \\
4.0 \mathrm{~g} / \mathrm{kg} / \text { day }\end{array}$ & $\begin{array}{l}2.5 \text { year } \\
7 \text { days' record }\end{array}$ & $\begin{array}{l}\text { In multiple linear regressions with adjustment } \\
\text { for sex and weight, height }(\mathrm{cm}) \text { was positively } \\
\text { associated with intakes of animal protein } \\
\text { (g/day) }[0.10 \pm 0.038 \text { ( } b \pm \mathrm{SE}) ; p=0.0 \mathrm{I}] \text { and } \\
\text { milk ( } 0.0047 \pm 0.002 ; p=0.007) \text {, but not with } \\
\text { those of vegetable protein or meat. }\end{array}$ & 2.5 year & $\begin{array}{l}\text { Cross-sectional } \\
63 \% \text { was animal protein }\end{array}$ \\
\hline $\begin{array}{l}\text { Koletzko, } 2009 \text { (29) } \\
\text { RCT Multi-center, } \\
\text { European } \\
\text { double-blind } \\
\text { intervention trial }\end{array}$ & $\begin{array}{l}\text { Infant formula } \\
\text { I.77 g protein } / 100 \mathrm{kcal} \\
\text { follow-on } \\
\text { formula } \\
2.2 \mathrm{~g} \text { protein } / 100 \mathrm{kcal}\end{array}$ & $\begin{array}{l}\text { Infant formula } \\
2.9 \mathrm{~g} \text { protein/ } / 100 \mathrm{kcal} \\
\text { follow-on formula } \\
4.4 \mathrm{~g} \text { protein } / 100 \mathrm{kcal}\end{array}$ & $\begin{array}{l}3,6,12 \text { and } 24 \\
\text { months3-day record }\end{array}$ & $\begin{array}{l}\text { A higher protein content of infant formula was } \\
\text { associated with higher weight in the first } 2 \\
\text { years of life but had no effect on length. } \\
\text { At } 24 \text { months, adjusted } \mathrm{z} \text { score for weight-for- } \\
\text { length in the lower protein formula group was } \\
0.20 \text { ( } 95 \% \mathrm{Cl}: 0.06,0.34 ; p=0.005 \text { ) lower than } \\
\text { in the higher protein group and did not differ } \\
\text { from that of the breastfed reference group. }\end{array}$ & 24 months & $\begin{array}{l}\text { For comparison, 'exclusively } \\
\text { breastfed' also followed }(<10 \% \\
\text { of feedings or }<3 \text { bottles of } \\
\text { formula/week during first } \\
3 \text { months) }\end{array}$ \\
\hline $\begin{array}{l}\text { Kourlaba, } \\
2008 \\
(42) \\
\text { Greece }\end{array}$ & $\begin{array}{l}\text { Mean intake } \\
\text { normal weight (E\%) } \\
16.5 \pm 2.6\end{array}$ & $\begin{array}{l}\text { Mean intake over } \\
\text { weight }(E \%) \\
16.6 \pm 2.5\end{array}$ & $\begin{array}{l}\text { I-5 year } \\
\text { 3-day record }\end{array}$ & $\begin{array}{l}\text { Protein intake was higher among 'at risk of } \\
\text { being overweight' or 'overweight' compared } \\
\text { with their } \\
\text { normal-weight counterparts. }\end{array}$ & I-5 year & Cross-sectional \\
\hline
\end{tabular}

Cross-sectional

GENESIS 
Papers seeing a positive association between protein intake and growth, and/or BMI

\begin{tabular}{|c|c|c|c|c|c|c|}
\hline $\begin{array}{l}\text { Author, year } \\
\text { (ref no.) } \\
\text { Country } \\
\text { Study design } \\
\text { (study name if applicable) }\end{array}$ & $\begin{array}{c}\text { Low intake } \\
\text { mean } \pm S D \\
\text { or } \\
\text { median ( } 25 \text { th- } 75 \text { th } \\
\text { percentiles) }\end{array}$ & $\begin{array}{c}\text { High intake } \\
\text { mean } \pm S D \\
\text { or } \\
\text { median (25th-75th } \\
\text { percentiles) }\end{array}$ & Age food & Effect & $\begin{array}{c}\text { Age weight/ } \\
\text { BMI }\end{array}$ & Comment \\
\hline $\begin{array}{l}\text { Manios, } 2008(44) \\
\text { Greece } \\
\text { Cross sectional }\end{array}$ & $\begin{array}{l}\text { g/day (Mean } \pm S D) \\
\text { Normal weight } 57.2 \pm 12.2 \\
\text { At risk OW } 59.6 \pm 12.4 \\
\text { OW } 59.9 \pm 12.8\end{array}$ & & $\begin{array}{l}\text { 1-5 year } \\
\text { 3-day record }\end{array}$ & $\begin{array}{l}\text { 'At risk of overweight' and 'overweight' } \\
\text { children consumed more total energy, protein, } \\
\text { and fat compared with their normal-weight } \\
\text { counterparts. }\end{array}$ & I-5 year & $\begin{array}{l}\text { Cross-sectional } \\
\text { Usual dietary intake at } \mathrm{I}-5 \text { years } \\
\text { NOTE: no difference in } \mathrm{E} \% \\
\text { Normal weight } 17.1 \pm 1.6 \\
\text { At risk OW } 17.1 \pm 1.5 \\
\text { OW } 17.1 \pm 1.5\end{array}$ \\
\hline $\begin{array}{l}\text { Morgan, } 2004 \text { (37) } \\
\text { UK Cohort }\end{array}$ & $\begin{array}{l}\text { Mean (SD) g meat/day lower } \\
\text { tertile } 4-24 \text { months: } \\
16 \pm 4-35 \pm 9\end{array}$ & $\begin{array}{l}\text { Mean }(\mathrm{SD}) \mathrm{g} \text { meat/day } \\
\text { upper tertile } 4-24 \\
\text { months: } 17 \pm 5-43 \pm 11\end{array}$ & $\begin{array}{l}4,8,12,16,20 \text { and } \\
24 \text { months } \\
\text { (intake calculated as } \\
\text { average intake } 4-24 \\
\text { months) } \\
7 \text { days' records }\end{array}$ & $\begin{array}{l}\text { Meat intake from } 4 \text { to } 12 \text { months was positively } \\
\text { and significantly related to weight gain } \\
(p<0.05) \text {; }\end{array}$ & 22 months & $1930-40$ \\
\hline $\begin{array}{l}\text { Öhlund, } 2010(4) \\
\text { Sweden } \\
\text { Prospective cohort } \\
\text { study }\end{array}$ & $\begin{array}{l}\text { Mean } 17-18 \text { months } 4 \\
\text { E\%: Boys/girls } 13.6 \pm 1.6 \\
\text { g/kg/day: Boys: } 2.9 \pm 0.6 \text {, girls } \\
\text { Mean } 4 \text { years } \\
\text { E\%: Boys: } 13.4 \pm 1.8 \text {, girls } 13.1 \\
\text { g/kg/day: Boys: } 2.7 \pm 0.6 \text {, girls }\end{array}$ & $\begin{array}{l}3.0 \pm 0.5: \\
\pm 1.6 \\
2.6 \pm 0.5\end{array}$ & $\begin{array}{l}\text { 6-18 months }+4 \text { years: } \\
\text { Monthly } 5 \text { days' records }\end{array}$ & $\begin{array}{l}\text { protein intake at } 17 / 18 \text { months and at } 4 \text { years } \\
\text { were positively associated with } \mathrm{BMI} \text { at } 4 \text { years }\end{array}$ & 4 year & \\
\hline $\begin{array}{l}\text { Sandström, } 2008 \text { (3I) } \\
\text { Sweden } \\
\text { CT/Partly RCT }\end{array}$ & $\begin{array}{l}25 \% \\
\alpha \text {-lactalbumin, with I5\% } \\
\text { glycomacropeptide GMP } \\
25 \% \alpha \text {-lactalbumin, with 10\% } \\
\text { GMP }\end{array}$ & $\begin{array}{l}\text { Standard formula: I I\% } \\
\alpha \text {-lactalbumin, I4\% } \\
\text { GMP }\end{array}$ & 6 weeks -6 months & $\begin{array}{l}\text { All formulas: I,96 g prot/ } 100 \mathrm{kcal} \text {. } \\
\text { The standard formula group gained significantly } \\
\text { more weight than did the breastfed infants. }\end{array}$ & 6 months & No volumes given \\
\hline $\begin{array}{l}\text { Scaglioni, } 2000 \text { (38) } \\
\text { Italy Prospective } \\
\text { cohort }\end{array}$ & $20 \mathrm{E} \%$ & $22 \mathrm{E} \%$ & $\begin{array}{l}I \text { and } 5 \text { year } \\
\text { Age-adjusted FFQ } \\
\text { and } 24 \mathrm{H} \text {-recalls }\end{array}$ & $\begin{array}{l}\text { Five-year old overweight children had a higher } \\
\text { percentage intake of proteins at the age of } \\
\text { I year than non-overweight children ( } 22 \text { vs. } \\
20 \%, P=0.024)\end{array}$ & 5 year & $\begin{array}{l}\text { Strongest risk factor for } \\
\text { overweight at } 5 \text { years was } \\
\text { parental overweight } \\
(p<0.000 \text { I) }\end{array}$ \\
\hline
\end{tabular}


Papers seeing a positive association between protein intake and growth, and/or BMI

\begin{tabular}{|c|c|c|c|c|c|c|}
\hline $\begin{array}{l}\text { Author, year } \\
\text { (ref no.) } \\
\text { Country } \\
\text { Study design } \\
\text { (study name if applicable) }\end{array}$ & $\begin{array}{l}\text { Low intake } \\
\text { mean } \pm S D \\
\text { or } \\
\text { median (25th-75th } \\
\text { percentiles) }\end{array}$ & $\begin{array}{l}\text { High intake } \\
\text { mean } \pm S D \\
\text { or } \\
\text { median (25th-75th } \\
\text { percentiles) }\end{array}$ & Age food & Effect & $\begin{array}{l}\text { Age weight/ } \\
\text { BMI }\end{array}$ & Comment \\
\hline $\begin{array}{l}\text { Skinner } \\
\text { 2004, } \\
(39) \\
\text { Prospective cohort }\end{array}$ & $\begin{array}{l}\text { Mean I4 E\% protein (longituc } \\
\text { years) }\end{array}$ & Hinal protein intake $2-8$ & $\begin{array}{l}2 \text { to } 8 \text { years. } \\
\text { longitudinal intakes } \\
\text { were based on } 27 \text { days } \\
\text { of dietary data per } \\
\text { child, collected in nine } \\
\text { sets of } 3 \text { days' data }\end{array}$ & $\begin{array}{l}\text { mean protein and fat intakes recorded between } \\
2 \text { and } 8 \text { years were positive predictors of BMI } \\
\text { at } 8 \text { years; mean carbohydrate intake over the } \\
\text { same time period was negatively related to BMI } \\
\text { at } 8 \text { years. }\end{array}$ & 8 year & \\
\hline \multicolumn{7}{|c|}{ Papers seeing no association between protein intake and growth and/or BMI } \\
\hline $\begin{array}{l}\text { Larnkjær, } 2009 \text { (30) } \\
\quad \text { RCT }\end{array}$ & $\begin{array}{l}\text { Infant formula } \\
\text { II.4 E\% protein at }\end{array}$ & $\begin{array}{l}\text { Whole milk } \\
14.2 \mathrm{E} \% \text { protein at } 12\end{array}$ & 9 and 12 months & $\begin{array}{l}\text { No effect of the milk intervention on change in } \\
\text { weight or length. }\end{array}$ & $\begin{array}{l}\text { Age weight/ } \\
\text { BMI } \\
9 \text { and } 12 \\
\text { months }\end{array}$ & Comment \\
\hline $\begin{array}{l}\text { Maillard } 2000(43) \\
\text { France } \\
\text { Cross-sectional }\end{array}$ & $\begin{array}{l}12 \text { months } \\
\text { Mean (range) of E\% at ages } 5 \\
\text { adjusted) } \\
\text { Boys: I4.0 (5.5-23.8) }\end{array}$ & $\begin{array}{l}\text { months } \\
\text {-II years (age and height }\end{array}$ & I-day record & No association related to E\% protein & 5-II year & $\begin{array}{l}\text { Cross- } \\
\text { sectional }\end{array}$ \\
\hline Räihä 2002 (5) CT/RCT & $\begin{array}{l}\text { Girls: } 14.3(7.4-23.5) \\
\text { Two experimental formulas } \\
\text { with a whey/casein ratio of } \\
70 / 30 \text { and a protein content } \\
\text { of } 1.8 \mathrm{~g} / 100 \mathrm{kcal} .\end{array}$ & $\begin{array}{l}\text { A conventional whey } \\
\text { adapted starter formula } \\
\text { with a whey/casein } \\
\text { ratio of } 60 / 40 \text { and a } \\
\text { protein content of } 2.2\end{array}$ & 3-day food record & $\begin{array}{l}\text { No differences were found between the four } \\
\text { feeding groups for weight- and length-gains or } \\
\text { for body mass indices (BMI). No differences in } \\
\text { energy intakes between the formula fed groups } \\
\text { could be found, whereas protein intakes were }\end{array}$ & $\begin{array}{l}30-120 \\
\text { days of age }\end{array}$ & \\
\hline $\begin{array}{l}\text { Van Vught, } 2010(40) \\
\text { Denmark Prospective } \\
\text { cohort }\end{array}$ & $\begin{array}{l}\text { E\% Boys: } 69.5 \pm 17.8 \text { Girls: } \\
63.4 \pm 15.2 \text { I-4th quintile of } \\
\text { BMI (leaner children) }\end{array}$ & $\begin{array}{l}\text { E/ } / 00 \mathrm{kcal} \\
\text { E\% } \\
\text { Boys: } 71.3 \pm 15.7 \\
\text { Girls: } 59.7 \pm 13.7 \\
\text { 5th quintile of BMI } \\
\text { (heavier children) }\end{array}$ & $\begin{array}{l}7 \text {-day records at } \\
6 \text { years }\end{array}$ & $\begin{array}{l}\text { less in infants fed the } 1.8 \mathrm{~g} / 00 \text { kcal formulas. } \\
\text { No association between protein intake and } \\
\text { linear growth. } \\
\text { However, amino acids could be important. High } \\
\text { arginine (ARG) intake, but not lysine (LYS), was } \\
\text { associated with linear growth ( } \beta=1.09 \text { (se } \\
0.54 \text { ), } P=0.05 \text { ) among girls. Also in girls, } \\
\text { change in fat mass index (FMI) showed a } \\
\text { stronger inverse association if combined with } \\
\text { high LYS, compared with low LYS intake. }\end{array}$ & $\begin{array}{l}6 \text { and } 9 \\
\text { years }\end{array}$ & $\begin{array}{l}\text { Possibly association with amino } \\
\text { acids rather that protein as such }\end{array}$ \\
\hline
\end{tabular}


Table 3. Protein intake and outcome BMI, growth, body composition, IGFS-I (6 clinical trials, 12 cohort, 5 cross-sectional)

Author, year

(ref no.)

Country

Study design

No. of

Exposure

Outcome

(incl age)

Effect/association

Study quality

(study name if applicable)

(incl age)

84 out of 96 boys Intake of total, dairy Concentrations of sIGF-I and

$(84 \%)$

and meat protein at 8 years

(14)

Denmark,

Cross-sectional markers for bone-turnover;
serum osteocalcin (s-OC),

bone-specific alkaline

but not significantly associated with sBAP and SCTX. Dairy Results not adjusted for mis/ tecreased $(P=0.05)$ sOC at a high meat protein

underreporting, no power calculaphosphatase (s-BAP) and intake ( $>0.8 \mathrm{~g} / \mathrm{kg})$, whereas meat protein increased tion.

C-terminal telopeptides of type I Total and meat protein intake was positively associated with meat, poultry and fish (but not pork, collagen (s-CTX) at 8 years $\operatorname{sBAP}(p \leq 0.04)$ but not significantly associated with sOC egg and $S C T X$.

Free sIGF-I was positively associated with total $(p<0.01)$

and dairy $(p=0.06)$ protein but not with meat protein.

Dorosty, 2000,

(32) UK

772 out of 889

Prospective cohort

(ALSPAC)

Gunnarsdottir 2003,

(3) Iceland

Nationwide

longitudinal cohort
$(87 \%)$

90 children

(4I boys)

Size at birth, growth and food intake in infancy
Protein intake at $18 \quad$ Timing of adiposity rebound months (g/day and E\%) (AR) (hypothesis: high protein intake promotes early $A R$ )

$\mathrm{BMI}$ at 6 years

(Weight and height were

measured at maternity wards and healthcare centers in Iceland $P$ throughout infancy and at 6 years)
No evidence of associations between protein intake, or any B

other dietary variable, and timing of the AR. Children with Measurement errors in dietary

$A R$ very early ( $\leq 43$ months) or early (from 49 but before recording not considered, very little $6 \mathrm{I}$ months) had parents with sig higher BMI and were sig data given about recordings, power more likely to have at least I obese parent.

Weight gain from birth to 12 months as a ratio of birth

weight was positively related to $\mathrm{BMl}$ at the age of 6 years in Measurement errors in dietary both genders $(\beta=2.9 \pm 1.0, p=0.008$, and $\beta=2.0 \pm 0.9$, recording not considered, power calculation not done 


\section{Günther,}

2006

(33)

Germany

Cohort study

DONALD

Germany
$3 \mid 3$ children with Habitual energy ad- Timing of adiposity rebound complete data justed protein intake (AR) (hypothesis: high protein ( 161 boys, $152 \quad(E \%$ and $g / k g$ RBW/day, intake promotes early $A R$ and girls) up to 7 years average between 2-3 higher BMI at AR)

dietary records between 12 and

24 months.

$\mathrm{RBW}=$ reference

body weight (adjusted

for age- and sex-

specific)

\section{Günther, \\ 2007 \\ (34) \\ 203 (104 M, 99 F) Protein intake at \\ 6, 12 and $18-24$ \\ months}

Prospective cohort

DONALD Study
$\mathrm{BMI}$ and\%BF (per cent body fat)

at 7 years of age

After adjusting for potential confounders, girls in the highest B

tertile (T3) of habitual energy-adjusted protein intake had a Measurement errors in dietary

significantly higher BMI-SDS at AR than those in $\mathrm{TI}$ ( $\mathrm{TI}:-0.6 \mathrm{I}$ recording not considered, power (95\% Cl: $-0.90 ;-0.3 \mathrm{I}), \mathrm{T} 2:-0.49(-0.79 ;-0.20), \mathrm{T} 3:-0.08$ calculation not done

$(-0.36 ; 0.20), p$ for difference $=0.01)$

A comparable association existed with habitual protein

intake expressed as g/kg RBW/day ( $\mathrm{TI}:-0.64(-0.93$;

$-0.36), \mathrm{T} 2:-0.22(-0.52 ; 0.09), \mathrm{T} 3:-0.25(-0.54 ; 0.04)$

$P=0.04$ )

In boys, there were no differences in BMI-SDS at AR

between tertiles of habitual protein intake (\% of energy or $g /$

$\mathrm{kg} \mathrm{RBW/day)} \mathrm{(P40.05).} \mathrm{Boys} \mathrm{in} \mathrm{the} \mathrm{lowest} \mathrm{tertile} \mathrm{of} \mathrm{habitual}$

energy-adjusted protein intake tended to experience

a later AR (TI: 6.0 (5.6; 6.4), T2: 5.5 (5.I; 5.9), T3: 5.4

$(5.0 ; 5.9)$ years, $p=0.07)$. But neither in girls nor in boys

was age at AR significantly different between tertiles of

habitual protein intake (\% of energy or $\mathrm{g} / \mathrm{kg} \mathrm{RBW} /$ day)

$(p>0.05)$.

A higher habitual protein intake between the age of 12 and

24 months was associated with a higher BMI-SDS at AR in girls, but not in boys. There was no consistent relation

between habitual protein intake in early childhood and timing of AR.

†protein $\rightarrow \uparrow B M I$

Consistently high protein intake 12, 18-24 months positively related to increased BMI SDS and \%BF at 7 years; BMI SDS 0.37 (95\% Cl 0.12. 0.6I) vs. 0.08 $(-0.09,0.26), p=0.04 ; \% \mathrm{BF} \mid 8.37(|7.29,1.5|)$ vs. 16.91 (16.19,17.66), $p=0.01$.

OR for BMI > 75th percentile $2.39(I .14,4.99), P=0.02$.

OR for \%BF $>75$ th percentile 2.28 ( $1.06,4.88$ ), $p=0.03$.

No effect of protein intake at 6 months.

Reported energy intake a bit low in one group $(<-20 \%$ of standard for age for the low-low group, Table 2 ) 


\section{Günther,}

2007

(35)

Germany

Prospective cohort,

DONALD Study

$03(102 \mathrm{M}$
Protein intake at 6 ,

18-24 months, 3-4 years, 5-6 years

\section{at 7 years of age}

\section{(per}

comments

Serum IGF-I, IGFBP, fasting insulin, C-peptide, index of
At 8 years a 7-day intervention with 540

$\mathrm{ml}$ milk-based drinks, either: I) whey with

low mineral content

(Ca and $\mathrm{P}$ )

(Whey-low), 2) whey with high mineral

content (Whey-high)

3) casein with low

mineral content

(Case-low), 4) casein

with high mineral

content (Case-high) insulin resistance, glucose

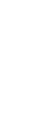

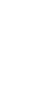

(2)


Hoppe, 24 boys

2004

(28)

Denmark

Intervention study

(7-day)

Hoppe,

2004

(36)

Denmark

Prospective,

observational cohor

Hoppe,

2004

(13)

Denmark

cross-sectiona
At 8 years a 7-day IGF-I concentrations and the After 7 days, the average protein intake increased in milk intervention with $53 \mathrm{~g}$ molar ratio of IGF-I/IGFBP-3 in group by $61 \%$; meat group $+54 \%$. protein daily, 12 boys as healthy, prepubertal children

I.5 I skimmed milk, and

12 boys as $250 \mathrm{~g}$ low fat meat. In addition, they were asked to eat their normal diet ad libitum. $\begin{array}{ll}142 \text { with data } & \text { Protein intake at } 9 \\ \text { from } 9 \text { months } & \text { months, and } 10 \text { years }\end{array}$ invited to 10 years Protein intake (as follow-up, 105 measured by SUN (74\% agreed to (serum urea nitrogen) take part), $5 \mathrm{I} M$ and IGF-I at 10 years and $53 \mathrm{~F}(+\mathrm{I}$ ?)

90 children Protein intake $(\mathrm{g} / \mathrm{kg} /$ (54 boys, 46 girls) day) at 2.5 years

The milk group increased s-IGF-I by 19\% $(p=0.001)$ an s-IGF-I/s-IGFBP-3 by $13 \%(p<0.000$ I $)$. No increase in the meat group. as such seem to stimulate IGF-I. This might explains the Weight and height at 10 years SUN at 9 months was a predictor for weight at 10 years: B but not $\mathrm{g} / \mathrm{kg} /$ day $)$ was a predictor for weight, $0.16(0.37$ $0.29), p=0.03$ [Wrong in table. Should be $0.16(0.037-0.29)$ ] and height $0.19(0.042-0.34), p=0.003$.

The 10th, 50th, and 90th percentiles of protein intake were $B$ $2.4,2.9$, and $4.0 \mathrm{~g} / \mathrm{kg} /$ day, respectively; $63 \%$ was animal
Associations between protein intake, serum insulin-like growt factor I (sIGF-I) concentrations, and height in in 2.5-year-old healthy children.
Conclusion: Compounds in milk and not a high protein intake additional $15 \mathrm{dl}$ of milk/250 g of meat positive effect of milk intake on growth seen in some studies. about how their habitual diet changed.

$0.96(0.28-1.6), p=0.006$ Protein $\mathrm{E} \%$ at 9 months was a Measurement errors in dietary predictor for weight at 10 years: $0.44(0.12-0.76), p=0.007$, recording not considered, power and height $0.5 \mathrm{I}(0.13-0.90), p=0.009$. Protein intake ( $g /$ day - calculation not done protein. In multiple linear regressions with adjustment for sex and weight, height $(\mathrm{cm})$ was positively associated with intakes of animal protein (g/day) $[0.10 \pm 0.038(b \pm \mathrm{SE})$; $p=0.01]$ and milk $(0.0047 \pm 0.002 ; p=0.007)$, but not with those of vegetable protein or meat. The sIGF-I concentration was significantly associated with intakes of animal protein $(\mathrm{I} .4 \pm 0.53 ; p=0.0 \mathrm{I})$ and milk $(0.049 \pm 0.024$; $p=0.045)$, but not with those of vegetable protein or meat. sIGF-I concentrations were positively associated with height $(0.019 \pm 0.008 ; p=0.02)$

Milk intake was positively associated with sIGF-I concentrations and height. An increase in milk intake from 200 to $600 \mathrm{~mL} /$ day corresponded to a $30 \%$ increase in circulating IGF-I. This suggests that milk compounds have a stimulating effect on sIGF-I concentrations and, thereby, on growth
Measurement errors in dietary recording not considered, power calculation not done

No power calculation

stated that protein intake is increased was actually taken, and very little 
Country

Study desis

participants

Koletzko,

\section{9}

(29)

European Multicente

study

RCT

\section{ourlaba,}

2008

(42),

GENESIS

Cross-sectional

\section{Children in five}

countries

(Belgium,

Germany, Italy,

Poland and Spain),

$n=934$ followed until 24 months; 636 in the lower

$(n=3 \mid 3)$ and

higher $(n=323)$

protein formula

groups and 298 in

the breastfed

group

weight at 24 months, expressed A higher protein content of infant formula was associate

with a lower ( 1.77 and as length and weight-for-length $\mathrm{z}$ with higher weight in the first 2 year of life but had no

$2.2 \mathrm{~g}$ protein/100 kcal, scores based on $2006 \mathrm{WHO} \quad$ effect on length. At 24 months, adj. z score for weight-

resp) or higher (2.9 growth standards.

and $4.4 \mathrm{~g}$ protein/100 Secondary outcome: weight,

for-length in the lower protein formula group was 0.20

(95\% Cl: $0.06,0.34 ; p=0.005)$ lower than in the higher

$\mathrm{kcal}$, resp) content of length, weight-for-length and

cow milk protein.

$\mathrm{BMI}$ at inclusion, at 3,6, 12 and group.

24 months

'exclusively breastfed'

also followed

or $<3$ bottles of

formula/week

during first

3 months)

Uncertain about Energy and

final number

macronutrient intake

analysed; between including protein,

2033 and 2346 children I-5 years
Interaction effect between

angiotensin-converting enzyme

I (ACE) I/D polymorphism

and diet on obesity-related

phenotypes.

DNA samples from 2102

children ( $1-5$ years) were

genotyped for the ACE I/D

polymorphism;

3 genotypes (II, ID, DD)
In general, differences were greatest at 12 months for

weight, weight-for-length and BMI.

Compared with breastfed, those fed high-protein formula

had sig higher $\mathrm{z}$ scores for weight, length, weight-for-length

and BMI at 24 months.

Intervention effect did not differ between

countries.

个protein $\rightarrow \uparrow B M$

Significant interactions found between the ACE I/D

polymorphism and protein intake on $\mathrm{BMI}$ and being

overweight ( $p<0.05$ for interaction)

Stratified analyses revealed that total energy is correlated

with WC and protein intake is associated with $\mathrm{BMI}$ and bein

overweight only among carriers of the D-allele (i.e. DD or

ID genotypes).

Protein intake was found to be positively associated with the likelihood of being overweight and with BMI (marginally)

among the DD homozygotes.

Protein intake was higher among 'at risk of being overweight'

or 'overweight' compared with their normal-weigh

counterparts.
No power calculation

(They've used Bonferroni correction, but it is not clear how) parents lost to follow-up had lower education, mothers more likely to be mokers, BUT no difference between xcluded due to non-compliance 
Country

Study desig

participants

Larnkjær, Healthy infants Infants randomized to Weight and length at 9 and 2009

either WM or IF (and either a daily fish oil

(WM) or infant

formula (IF)

pplement or no

supplement. $(2 \times 2$

design)

Maillard

2000

(43)

France

Cross sectional
50I; 280 boys,

221 girls (aged

$5 \pm 11$ years)

tary intake at

-II years

Energy, protein and

other nutrients

RQ:

associations between

several adiposity

indices and the

nutrient intake

The associations were

looked for according

to current dietary

recommendations, an

according to reported

energy intake to basal

metabolic rate ratios

$(\mathrm{EI}=\mathrm{BMR})$ and gender
Height and weight, four

kinfolds (biceps, triceps,

subscapular, suprailiac), waist

and hip girths, were measured.

Sum of skinfolds (SSF), body

mass index (BMI), and relative

weight (RW) were calculated.

Energy intake (El), percentage

of energy intake ascribed to

carbohydrates (\%EIC), complex

carbohydrates (\%EICC), fats

\%EIF), saturated fats (\%EISF)

and proteins (\%EIP)
WM or IF no effect on change in weight and length.

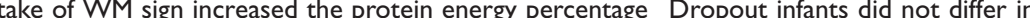
(PE\%; $p<0.00 \mathrm{I})$ and SUN $(p=0.0 \mathrm{I})$. PE\% was 14.2 in WM birth or breast-feeding and $\mathrm{II} .4$ in IF at 12 months. But no effect of the milk intervention on change in weight or length. Intake of fish oil had no effect on the outcomes.

In multiple linear regressions analyses performed with hierarchical mixed models, adiposity indices were characteristics from those who finished the study, but they were $1.6 \mathrm{~cm}$ shorter at 9 months $(95 \% \mathrm{Cl} 3.01,0.21, p=0.039)$

This could be problematic as it is a study about growth.

B

Confounders not taken adequately significantly and inversely associated in girls with \%EIC (all into consideration

$P$-values $<0.02$ ), and positively with \%EIF (all $p$-values $<0.05$, waist girth and BMI excepted). Similar but non-significant trends were observed in boys. The relationships were not linear, and thresholds close to current dietary recommendations were highlighted. When\%EIF was low, a lower percentage of energy intake ascribed to\%EISF was associated with thinness. These associations remained after the exclusion of children who had an El =BMR_I.50 For both fat and carbohydrate, a substantial percentage of toddlers and preschoolers had usual intakes outside the acceptable macronutrient distribution range, whereas protein was less than this range. 'At risk of overweight' and 'overweight' children consumed more total energy, protein, and fat compared with their normal-weight counterparts, whereas no differences were found for micronutrient intakes. The estimated prevalence of inadequacy was found to be between 10 and $25 \%$ for niacin, vitamin $\mathrm{E}$, and folate Usual intakes exceeding the Tolerable Upper Intake Levels were recorded for zinc and copper. 
(44)

Greece

Cross-sectional

(GENESIS cohort)

\section{Morgan}

2004

(37)

UK

Prospective cohort

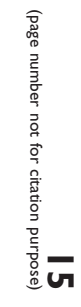

Describe nutrient Anthropometrical indexes (i.e. For both fat and carbohydrate, a substantial percentage of B intake: (a) usual energy body weight, recumbent length, toddlers and preschoolers had usual intakes outside the and macronutrient intake in the total population as well as by children's weight status, and (b) inadequate or excessive nutrient intakes compared with children's requirements. and stature) obtained and BMI was calculated The Nutstat acceptable macronutrient distribution range, whereas Participation rate not clear, study module of Epilnfo was protein was less than this range. 'At risk of overweight' and difference in protein E\% between the determine children's age- and sex- and fat compared with their normal-weight counterparts, risk OW $17.1 \pm 1.5$, OW $17.1 \pm 1.5)$ specific percentiles for weight, whereas no differences were found for micronutrient length, and body mass index. The intakes. The estimated prevalence of inadequacy was found weight-for-length percentiles to be between 10 and $25 \%$ for niacin, vitamin $E$, and folate. were used to classify children up Usual intakes exceeding the Tolerable Upper Intake Levels to 24 months old as 'overweight' were recorded for zinc and copper.

( $\geq 95$ th percentile), whereas children older than 24 months were classified as 'at risk of overweight' ( $\geq 85$ th and $<95$ th percentile) and 'overweight' ( $\geq 95$ th percentile) using the body mass index-for-age percentiles.

I. Total red and white meat intake (g) from 4 to 12 months as a continuous variable,

i.e. total meat intake over 21 days between 4 and 12 months.

2. Total red and white meat intake (g) from 4 to 16 months as a continuous variable, i.e. total meat intake over 28 days between 4 and 16 months. circumference at the ages of 4 , significantly related to weight gain $(p<0.05)$; further analysis Loss to follow-up not reported $8,12,16,20$ and 24 months suggested this association might be mediated via protein intake but was independent of energy, zinc or iron intake.

No power calculations

There was no interaction between meat intake and breastfeeding on growth. These findings remained after adjustment for potential confounding factors. 


\section{Total red and white} meat intake $(g)$ from 4 to 24 months as a continuous variable,

i.e. total meat intake over 42 days between

4 and 24 months.
Öhlund, 2010

(4) Sweden

Prospective cohort

study
127 healthy

children (63 girls and 64 boys) at

4 years of age followed

prospectively from 6 to 18 months of age

Räihä, 2002 (5)

Finland CT
113 term infants, breast-fed and formula-fed.

\section{Current and previous} dietary intake
Weight, height BMI, Mid-upper arm circumference, subcutaneous fat at 4 years of age
Fourteen percent of the girls and $13 \%$ of the boys were overweight (age-adjusted BMIX25) and $2 \%$ of the girls and Loss of follow-up more than $20 \%$ $3 \%$ of the boys were obese (age-adjusted BMIX30). Thirty- No power calculation

four percent and $9 \%$ of the fathers and 19 and $7 \%$ of the mothers were overweight and obese, respectively. BMI at 6-18 months was a strong predictor of BMI at 4 years. Intake of protein in particular, and also of total energy and carbohydrates at $17 / 18$ months and at 4 years, was positively associated with BMI at 4 years. Although BMI at $6-18$ months was the strongest predictor of BMI at 4 years, in the final multivariate models of the child's BMI, protein intake at $17-18$ months and at 4 years, energy intake at 4 years and the father's - but not the mother's - BMI were also independent contributing factors

No differences were found between the four feeding groups $B$

\section{Parents were instructed increment in anthropometrics} for weight- and length-gains or for body mass indices (BMI). Randomization method not stated exclusively breastfeed or feed the assigned formula up to

120 days of age days of age (unit/month) Body weight and length were

3 isocaloric formulas birth at $30,60,90$ and 120 days. source and content Blood was collected for No differences in energy intakes between the formula fed adequately groups could be found, whereas protein intakes were less in Differences between drop-outs and infants fed the $1.8 \mathrm{~g} / 100 \mathrm{kcal}$ formulas. Plasma urea levels of participants nor reported the infants fed the $1.8 \mathrm{~g} / 100 \mathrm{kcal}$ formulas were closer to those found in the breast-fed infants.

biochemical measurements at were studied and

compared with breast

milk) Calculated energy

and protein intakes
30,60 , and 120 days. 
Country

Study desig

(study name if applicable)

No. of

Exposure

Outcome

Study quality

Sandström,

2008

(3I)

Sweden

CT/Partly RCT

80 (HealthyGA:

36- 42

weeksBWT:

Scaglioni,

2000

(38)

Italy

Prospective cohort

Skinner

2004

(39)

Prospective cohort
Energy and macronu- BMI, age of adiposity rebound

trient intakes at each was determined

study point
Standard vs two for- $\quad$ Growth

varying in G Ly- $\quad$ - General health

$\alpha$-lactalbumin i.e. 3 urea nitrogen, amino

formulas $w$. bovine

fractions rich in $\alpha$ -

actalbumin $\mathrm{w}$. varying

GMP vs. breast feeding

(as control) All formu-

las: 1,96 g prot/ $100 \mathrm{kcal}$.

Nutrients/ early

Anthropometry at I, 5 years

macronutr. Intake,

Parental factors
Effect/association

Formula intake was similar in different groups.

Weight gain in the alpha-lactalbumin-enriched formula

groups was similar to that of the breastfed infants. The

standard formula group gained significantly more weight than did the breastfed infants.

All formula-fed infants had significantly higher plasma concentrations of most essential amino acids at 4 and

6 months than did the breastfed infants, and serum urea

nitrogen was also higher in the formula-fed infants. Insulin and leptin concentrations did not differ between groups.

The prevalence of overweight at the age of 5 years was strongly associated with parental overweight $(p<0.000 \mathrm{I})$.

Five-year old overweight children had a higher percentage intake of proteins at the age of I year than non overweigh children ( 22 vs. $20 \%, p=0.024)$. Multiple logistic analysis confirmed that protein intake at I year-of-age was associated with overweight at 5 years $(p=0.05)$. In children born from overweight mothers, prevalence of overweight at the age of 5 years tended to be higher in bottle-fed than in breast-fed ones (62.5 vs. $23.3 \%, p=0.08$ ). Conclusion: Parental overweight is a major risk factor for childhood overweight in the first years of life, but an early high protein intake may also influence the development of adiposity.

Children's BMI at 8 years was negatively predicted by age of B adiposity rebound and positively predicted by their BMI at Baseline not clearly indentified, 2 years. Mean protein and fat intakes recorded between 2 and 8 years were positive predictors of BMI at 8 years; mean carbohydrate intake over the same time period was negatively related to $\mathrm{BMI}$ at 8 years. $\mathrm{R} 2$ values indicated that these three-variable models predicted $4 \mid-43 \%$ of the variability in $\mathrm{BMI}$ among children. $\mathrm{BMI}$ of $23 \%$ of the children exceeded the 85th CDC percentile.
No power calculation reported, compliance unclear, energy intake nclear, results not analysed blind, unclear about between measure ments errors

Measurement errors in dietary

reporting not considered

Energy intake little bit high

No power calculation

easurement errors in dietary

recording not considered, power

calculation not done 
Country

Study design

No. of

Exposure

Outcome

(incl age)

(incl age)

Study quality

Van Vught, 2010

(40)

Protein intake,

comments

Denmark

Prospective cohort especially the amino

acids: Lysine (LYS)

Arginine (ARG)

\section{Van Vught, 2009}

(4I)

Denmark

Prospective cohort
384 of originally Diet

$$
771
$$

Protein, amino acids:

ARG, LYS
Growth \& body composition

Fat mass index (FMI)

No association between protein intake and linear growth. However, amino acids could be important. High ARG intake, but not LYS, was associated with linear growth ( $\beta=1.09$ (se 0.54), $p=0.05$ ) among girls.

Furthermore, in girls, change in FMI had a stronger inverse association with high ARG intake, if it was combined with high LYS intake, instead of low LYS intake $(p=0.03)$. No associations were found in boys.

In prepubertal girls, linear growth may be influenced by habitual ARG intake and body fat gain may be relatively prevented over time by the intake of the amino acids ARG and LYS.

Skinfold thickness was measured Among lean girls inverse associations were found between at ages 8-10 years and 14-16 protein as well as arginine and lysine intake and change year. BMI and Body fat\% was estimated from skinfold measurements
Energy adjustment not done

No power calculation $\begin{array}{ll}\text { in fat mass index }(\beta=-1.12+I-0.56, p=0.03, & \text { Measurement errors in dietary } \\ \beta & \text { reporting not consideredOnly } 49.8 \%\end{array}$ $\beta=-1.10+I-0.53, p=0.04, \beta=-1.13+I-0.51$,

of original sample took part in $P=0.03$ respectively). Furthermore among girls with a body baseline ( $57 \%$ of those still living in mass index in the 5 th quintile, protein intake was associated area took part in follow-up) with DeltaFFMI $(p=0.04)$, and more specific when LYS intake was high, ARG intake was associated with DeltaFFMI $(p=0.04)$. No associations were found in boys. 
Author, year

(ref no.)

Country

Study design

(study name if

No. of

Exposure

Outcome

Study quality

applicable)

participants

(incl age)

Effect/association

comments

Alexy, 2005 (47) 22

Germany

Potential renal acid load

(incl age)

By chance findings not considered

Prospective (PRAL) calculated from variables (cross-sectiona

Protein intake ( $\mathrm{g} / \mathrm{day}$ ) was positively associated with all bone dietary protein, $\mathrm{P}, \mathrm{Mg}, \mathrm{K} . \quad$ data I measurement)

cohort,

Exposure to protein, 6-18 years

PRAL was negatively associated with cortical area $(p=0.0075)$

$38 \%$ had non-valid records (Goldberg and

subgroup

PRAL and $\mathrm{Ca}=$ input

and bone mineral content $(p=0.0055)$. Explained $2 \%$ of variation for both.

DONALD

(Muscle area accounted for 24-36\%, $p<0.00$ I) Ca intake

non-sign for all bone variables. given as to level of underreporting among those remaining in study.

Mean energy intake ca 74\% (pre-pubescent girls) $-84 \%$ (pre-pubescent boys) of recommendation for age.

Bounds 2005

(48) USA

$52(25 \mathrm{M}, 27 \mathrm{~F})$

Children's dietary intake, Total BMC (bone miner height, weight, and level of content, g) and BMD sedentary activity were assessed as part of a (bone mineral density, $g /$ longitudinal study from ages 2 months to 8 years

Budek, 2007,

109 (46 M, 63 F) Milk and meat protein

49) Denmark

Cross-sec-

tional

intake at 17 years.

hypotheses that tota
The aim was to test the

protein intake is positively

associated with bone

mass, and that milk and

meat protein intake

isdifferently associated

with bone mass in

adolescents bone mineral content

(BMC) at 17 years

Factors positively related to children's BMC at age 8 years included longitudinal intakes (ages 2 to 8 years) of protein, $\mathrm{cm}^{2}$ ) at age 8 years. phosphorus, vitamin $\mathrm{K}$, magnesium, zinc, energy, and iron

Measurement errors not considered (but it is stated that throughout this longitudinal height; weight; and age $(p \leq 0.05)$. Factors positively related to study, mothers received training from RDs children's BMD at age 8 years included longitudinal intakes of on estimating portion sizes and keeping protein and magnesium $(p \leq 0.05)$. Female sex was negatively precise food records.and the RDs reviewed associated with BMC and BMD at age 8 years $(p \leq 0.05)$ food records for completeness and accuracy Children's bone mineral indexes at ages 6 and 8 years were at each interview), no power calculation strongly correlated $(r=0.86, p<0.000$ I for BMC; $r=0.92$, $p<0.000$ I for BMD.

The mean total protein intake $(\sim 1.2 \mathrm{~g} / \mathrm{kg})$ was modestly higher than that recommended. Total and milk $(\sim 0.3 \mathrm{~g} / \mathrm{kg})$ protein intake, but not meat protein intake $(\sim 0.4 \mathrm{~g} / \mathrm{kg})$, was mis/underreporting, girls reported energy positively associated with size-adjusted BMC $(p \leq 0.05)$. The intake in lower range but OK positive association between milk protein intake and size-

adjusted BMC remained significant after correction for energy,

calcium, and physical activity $(p \leq 0.0 \mathrm{I})$ and did not seem to be mediated via current serum IGF-I. None of the analyzed

protein sources was significantly associated with size-adjusted BA. Conclusions Our results suggest that some components of milk protein may promote bone mineralization. Further studies are needed to elucidate this phenomenon 
Study design

(study name if

applicable)

No. of

\section{Exposure}

(incl age)

Outcome

(incl age)

Effect/association

Budek,

2007

81 boys (out o

Intake of total, dairy and

96 eligible boys) meat protein

(14)

Denmark,

Cross-sec-

tional

\section{Concentrations of sIGF-}

and markers for bone-

turnover (serum

osteocalcin (sOC),

bone-specific alkaline

phosphatase (sBAP) and
C-terminal telopeptides

of type I collagen (sCTX)

measured by

immunoassay)

24 boys

2007

(46)

Denmark

Short-term

(7 days)

intervention

study
Protein intakeOne group: Markers for milk (I.5 I/day) and the bone-turnover: Serum other group: meat $(250 \mathrm{~g}$ day)

bone-specific alkaline

of protein.

Otherwise, habitual diet.
Dairy protein was negatively associated with $\mathrm{SOC}$

$(p=0.05)$ but not significantly associated with sBAP and SCTX. Further analyses showed that dairy protein

decreased $(p=0.05) \mathrm{sOC}$ at a high meat protein intake

$(>0.8 \mathrm{~g} / \mathrm{kg})$, whereas meat protein increased $(p=0.03)$

sOC at a low dairy protein intake $(<0.4 \mathrm{~g} / \mathrm{kg})$. Total and meat protein intake was positively associated with $\operatorname{sBAP}(p \leq 0.04)$ but not significantly associated with sOC and sCTX. Free sIGF-I was positively associated with total $(p<0.0 \mathrm{I})$ and dairy $(p=0.06)$ protein but not with meat protein. Our results indicate that dairy and meat protein may exhibit a distinct regulatory effect on different markers for bone turnover. Future studies should focus on differential effects of dairy and meat protein on bone health during growth.

Baseline sOC, sBAP and sCTX were not sign different between the groups. After 7 days, the average protein intake increased in both groups by $47.5 \mathrm{~g}$; the milk group had higher $(p<0.0001)$ calcium intake; sOC and sCTX decreased $(p<0.04)$ in the milk group $(-30.9 \% ;-18.7 \%$, C-terminal telopeptides of respectively) compared with the meat group $(+6.4 \% ;-1.0 \%$, type I collagen (sCTX) respectively) and sBAP decreased $(p=0.06)$ both in measured by immunoassay the milk $(-3.9 \%)$ and the meat group $(-7.5 \%)$. The milk 8 years group had significantly higher calcium intake compared with the meat group and this could also affect the decline observed in bone turnover in the milk group. Whether this decline promotes higher bone mineral accretion during growth needs to be further studied according to the authors.
B

Results not adjusted for mis/underreporting, no power calculation.

In discussion: 'Meat protein intake was estimated from the intake of red meat, poultry and fish.' Why is fish included? What about pork? Egg? 'Plant protein intake was estimated from the difference between total protein intake and dairy, meat and egg protein intake.'

No power calculationCompliance is not reported. It is stated that protein intake is increased but nothing about how much of the additional $15 \mathrm{dl}$ of milk/250 $\mathrm{g}$ of meat was actually taken, and very little about how their habitual diet changed. (I.5 I skim milk $=2.3 \mathrm{MJ}$ and $+23 \%$ of mean energy intake, $250 \mathrm{~g}$ meat $=\mathrm{ca} \quad 1.6 \mathrm{MJ}$ and $+16 \%$ of mean energy intake. The average increase was total $+13 \%$ in the milk group and $+3 \%$ in the meat group). 


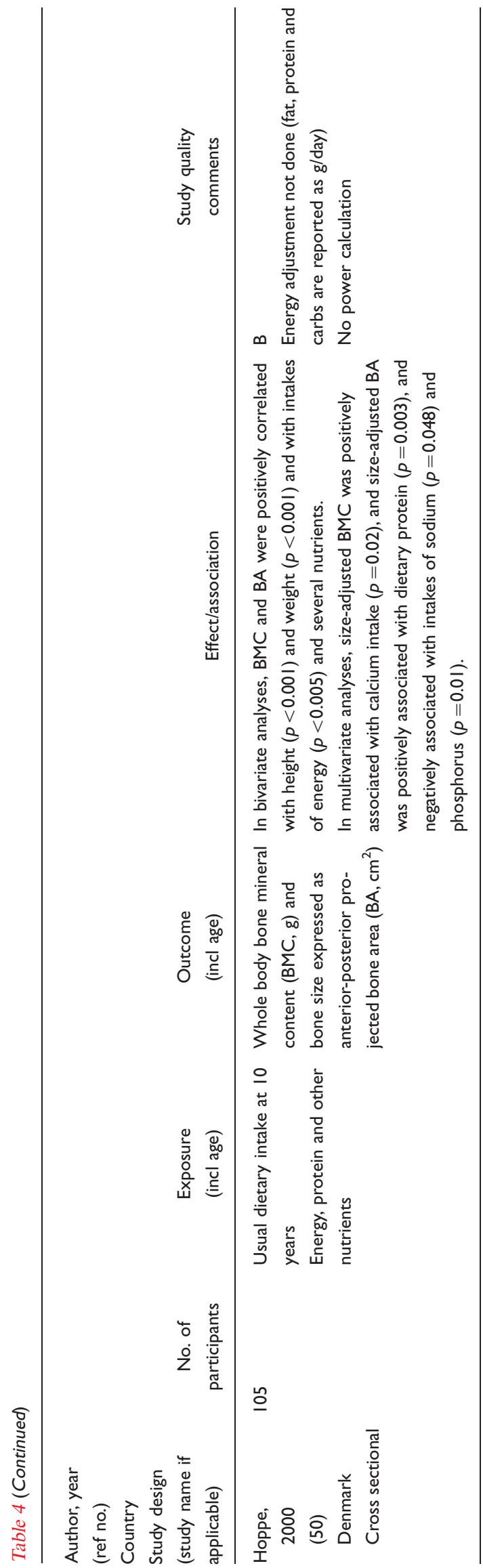

important, but different, in the growth-stimulating effect of milk.

Hoppe et al. (28), graded B, conducted an intervention study $(n=24)$ to examine whether an increase in animal protein intake could increase concentrations of sIGF-I in serum(s) and the molar ratio of sIGF-I/sIGFBP-3 in prepubertal children. Eight-year-old boys with a habitual milk intake of at least $500 \mathrm{ml} /$ day were asked to take an extra $53 \mathrm{~g}$ protein daily for a week - extra daily intake was 1.51 of skimmed milk by 12 boys and $250 \mathrm{~g}$ of low fat meat by 12 other boys. In addition, they were asked to eat their normal diet ad libitum. Dietary intake was assessed using two repeated 3-day weighed food records (2 weekdays and 1 weekend day); the first kept before the intervention (days -3 to 0 ) and the second at the end of the intervention (days 5 to 7). Measurement errors in the dietary recordings were not considered, but the importance of maintaining usual dietary intake was emphasized to the families.

After 7 days, the average protein intake increased to 4.0 $\mathrm{g} / \mathrm{kg} /$ day $(+61 \%)$ in the milk group and to $3.7 \mathrm{~g} / \mathrm{kg} /$ day $(+54 \%)$ in the meat group. High intake of milk increased concentrations of sIGF-I $(+19 \%)$ and sIGF-I/sIGFBP-3 $(+13 \%)$, while no increases were seen in the meat group. The authors conclude that compounds in milk, and not a high protein intake as such, seem to stimulate sIGF-I, and that this might explain the effect of milk intake on growth seen in some studies.

Note: The total reported energy intake by the milk group increased by $13 \%$ and the group gained on average $550 \mathrm{~g}$ of weight during the intervention week compared with a 3\% increase in energy intake and no change in weight in the meat group. SUN was used as a biomarker of protein intake, but SUN increased similarly in the two groups although reported protein intake per $\mathrm{kg}$ and day increased $20 \%$ more in the milk group $(+1.7 \mathrm{~g} / \mathrm{kg} /$ day vs. $+1.4 \mathrm{~g} / \mathrm{kg} /$ day in the meat group). There was no difference in intake at baseline $(2.32 \mathrm{~g} / \mathrm{kg} /$ day vs. $2.27 \mathrm{~g} /$ $\mathrm{kg}$ /day). No power calculation was reported.

Koletzko et al. (29), graded A, conducted a doubleblind, randomized controlled trial in a European multicenter study in five countries to test the hypothesis that a higher early protein intake leads to more rapid growth in the first 2 years of life. Eight-week-old healthy formulafed infants $(n=1138)$ were randomly assigned to a lowor high-protein diet (cow-milk-based infant formula with 1.77 vs. $2.9 \mathrm{~g}$ protein $/ 100 \mathrm{kcal}$ and follow-on formula with 2.2 vs. 4.4 g protein $/ 100 \mathrm{kcal})$. The protein content represented approximately the lowest and highest acceptable levels in the range given in the European Union (EU) directives from 1991. An observational group of infants exclusively breastfed for the first 3 months of life was also included in the study $(n=619)$ (Note: Exclusive breastfeeding was defined as $<10 \%$ of feedings or less than three bottles of formula/week). 
Berkey, 200067 girls Dietary intake (kcal/ Age at menarche,

(53) followed

USA from utero

Prospective to 18 years

cohort

1930s-

1940 s day, animal protein age at peak height g/day, vegetable protein g/day, total peak growth fat $g /$ day) BMI averaged over multiyear periods (I-2, 3-5, 6-8 years $+\mathrm{I}$ and 2 years before peak growth)

Günther,

(54)

112 children Protein at 12

(92 had data months, 18-24

Germany menarchel 5-6 years (total

DONALD voice break) Prospective

cohort

Study

Weight, height vegetable protein, height

and dairy, meat velocity and cereal protein 3)

intake)+Energy

intake,

carbohydrates,

fiber and fat intake break
For peak growth velocity the same three factors emerged in all age periods; more calories, more animal protein and lower BMI were consistently associated with higher peak growth velocity (factors closer to puberty more important).

Timing of puberty was predicted by protein intake and height. Higher animal protein (energy adjusted) intake and less vegetable protein at 3-5 years had earlier menarche (+ I SD animal protein intake gave 0.63 year earlier menarche than $-\mathrm{ISD}$, and peak height growth was $+0.6 \mathrm{~cm} / \mathrm{year}$ ).

Higher dietary fat intake at I-2 years associated with earlier peak growth (+I SD fat intake gave 0.63 year earlier peak growth velocity than $-\mathrm{ISD}$ ) and higher calorie intake at I-2 years gave higher peak height velocity (+I SD calorie intake gave $+1.1 / \mathrm{cm} /$ year than $-I S D)$ and higher animal protein intake at 6-8 years had earlier peak growth.

Later age at menarche associated with lower age at peak growth $(r=0.8 \mathrm{I}, p<0.05)$ and lower peak growth velocity $(r=-0.4 \mathrm{I}, p<0.05)$

Timing of puberty; Higher animal protein intake (E\%) at 5-6 years was associated with earlier puberty. Highest tertile of intake A

1) Age at take-off of had ATO 0.6 year earlier than the lowest tertile $(p=0.048)$. Similar tendency at 3-4 years. Vegetable protein intake $(\mathrm{E} \%)$ associated with a later ATO

Protein intake from cow milk and dairy products at age 5-6 years (but not meat) was associated with an earlier ATO [mean ATO, 95\% Cl; tertile I: 9.5, 9.2-9.8; tertile 2: 9.5, 9.3-9.8; tertile 3: 9.1, 8.8-9.4 year; $p$ trend $=0.04]$.

Children with higher animal protein intake $(E \%)$ at $3-4$ and $5-6$ years had earlier APHV $[3-4$ years: tertile I: 12.5, I2.2-12.9; tertile 3: 12.0, II.7-12.3 years; $p<0.05$ ], [5-6 years: tertile I: I2.8, I2.5-13.I; tertile 3: I2.0, Menarche/voice I.7-12.3 years; $p<0.05$ ], while those with high vegetable protein intake had later APHV [3-4 years: tertile I: I2. I, I I.8-12.5; tertile 3: I2.6, I2.3-13.0 years; $p$-trend $=0.02$ ], [5-6 years: tertile I: I2.2, II.8-13.6; tertile 3: 12.6, I2.2-13.0 years; $p=0.04]$.

Higher animal protein intake (especially milk) at 3-4 years tended $(p=0.06)$ to be (and at 5-6 years was $(p=0.02)$, associated to earlier menarche/voice break and later for high vegetable protein intake $(0.02$ and 0.03 respectively).

Adjustment for confounders did not change all these associations.
Drop-out rate high (43\%) 
Remer,

2010 protein intake at I

I) Age at take-off

Germany.

DONALD

puberty ons

growt

spurt (ATO)

2) Age at peak

height velocity

(APHV)

cohort

Study

Shi,

2009

Anthropometry;

Nutrient intake

including protein

and also glycemic

$\begin{array}{ll}\text { Germany, } & \text { and also glycemic } \\ \text { DONALD } & \text { index and glycemic }\end{array}$

Prospective load; Body

costortiv

composition such as

fat mass, fat-free

mass

genital (boys)

development

androgen

status (AA)
3) Menarche/voice, $\quad(p<0.05$ each $)$ and tended to be negatively associated with age at menarche/voice break

4) Tanner stage $2 \quad(p=0.07)$

for breast (girls) and

Adrenachal $\quad \mathrm{AA}$ is depending on $\mathrm{FM}(5 \%, p<0.000 \mathrm{I})$ and protein intake $(1 \%, p<0.05)$. indepently of animal protein intake. Children with a higher Adrenal Androgen (AA) secretion had a 1.5-year earlier beginning of pubarche and a 0.8-year earlier beginning of B2-G2 than those with

lower AA excretion.

$$
(p=0.07) \text {. }
$$

B. No information on physical activity, statistical power, time of baseline or exposure variable not totally clear. Note: refer to previous papers for validation or exact description of dietary methods 
Author, year

(ref no.)

Country

Study design

(study name if

No. of

Exposure

Outcome

Study quality

applicable)

participants

(incl age)

Effect/association

comments

\begin{tabular}{|c|c|c|c|c|c|}
\hline $\begin{array}{l}\text { Hoppe, } \\
\text { 2009, } \\
\text { (27)Denmark } \\
\text { CT }\end{array}$ & $\begin{array}{l}831 \text { invited, } \\
89 \text { agreed to } \\
\text { participate. }\end{array}$ & $\begin{array}{l}2 \times 2 \text { factorial design: } \\
540 \text { ml milk-based } \\
\text { drinks, either: } \\
\text { I) whey with low } \\
\text { mineral content (Ca and } \\
\text { P) (Whey-low), } \\
\text { 2) whey with high } \\
\text { mineral content (Whey- } \\
\text { high), 3) casein with low } \\
\text { mineral content (Case- } \\
\text { low), } 4 \text { ) casein with high } \\
\text { mineral content (Case- } \\
\text { high) } \\
\text { RQ: To examine the } \\
\text { effects of the two major } \\
\mathrm{n} \text { milk protein fractions, } \\
\text { whey and casein, and } \\
\text { milk minerals (Ca and P) } \\
\text { in a } 2 \times 2 \text { factorial design } \\
\text { on IGFs and glucose- } \\
\text { insulin metabolism }\end{array}$ & $\begin{array}{l}\text { Serum IGF-I, IGFBP, } \\
\text { fasting insulin, C- } \\
\text { peptide, index of } \\
\text { insulin resistance, } \\
\text { glucose }\end{array}$ & $\begin{array}{l}\text { No interactions between milk mineral groups (high, low) and milk } \\
\text { protein groups (whey, casein). The milk protein intervention } \\
\text { groups were combined. } \\
\text { Average daily protein intake was increased by I7\% by the whey } \\
\text { drink, from } 58 \mathrm{~g} / \mathrm{day}(2.23 \mathrm{~g} / \mathrm{kg} \text { per day, I } 2.98 \mathrm{PE} \%) \text { to } 68 \mathrm{~g} / \text { day } \\
\text { ( } 2.56 \mathrm{~g} / \mathrm{kg} \text { per day, I5.42 PE\%) }(p<0.00 \mathrm{I}) \text {, and by } 5 \mathrm{I} \% \text { by the } \\
\text { casein drink, from } 68 \mathrm{~g} \text { per day }(2.30 \mathrm{~g} / \mathrm{kg} \text { per day, I } 4.30 \mathrm{PE} \%) \text { to } \\
\text { I03 g per day ( } 3.44 \mathrm{~g} / \mathrm{kg} \text { per day, } 23.40 \mathrm{PE} \%)(p<0.00 \mathrm{I}) \text {. } \\
\text { In the whey group, fasting insulin increased by } 2 \mathrm{I} \%(p=0.006) \text {, } \\
\text { with no change in IGF-I ( } p=0.27) \text {. } \\
\text { In the casein group, serum IGF-I increased by I5\% }(p<0.000 \mathrm{I}) \text {, } \\
\text { whereas there was no change in fasting insulin ( } p=0.36) \text {. } \\
\text { No independent effects of a high milk mineral intake on IGF-I and } \\
\text { insulin. } \\
\text { Increase in serum urea nitrogen (SUN), and the molar ratio } \\
\text { of IGF-I/IGFBP-3 was significantly higher in the combined } \\
\text { casein-group than in the combined whey group. } \\
\text { Conversely, whey increased fasting insulin more than did casein. }\end{array}$ & $\begin{array}{l}\text { B } \\
36 \% \text { drop-out. No details given. Remaining diet } \\
\text { unclear. Energy intake at baseline reported and } \\
\text { credible level. Measurement errors not } \\
\text { considered } \\
\text { Can't find that they say very much about } \\
\text { compliance. They state in Discussion that } \\
\text { 'However, the diet was appropriately recorded, } \\
\text { and this has been controlled for in the analysis.' } \\
\text { Intake of energy, protein and milk, }+ \text { SUN } \\
\text { (biomarker for protein intake) was controlled for } \\
\text { in the analysis (but how?). Nothing more is said. } \\
\text { 2e) They use SUN as a biomarker for protein } \\
\text { intake, but don't say anything about the rest of } \\
\text { the dietary intake. }\end{array}$ \\
\hline $\begin{array}{l}\text { Sandström, } \\
2008 \\
(31) \\
\text { Sweden } \\
\text { CT } \\
\text { Partly } \\
\text { RCT }\end{array}$ & $\begin{array}{l}80 \text { (Healthy } \\
\text { GA:36-42 } \\
\text { weeks } \\
\text { BWT: } \\
2500-5000 \mathrm{~g} \text { ) }\end{array}$ & $\begin{array}{l}\text { Standard vs. two formulas } \\
\text { varying in G } \\
\text { Lycomacropeptide (GMP) } \\
\text { and } \alpha \text {-lactalbumin i.e. } 3 \\
\text { formulas w. bovine whey } \\
\text { fractions rich in } \alpha \text { - } \\
\text { lactalbumin w. varying } \\
\text { GMP vs. breast feeding } \\
\text { (as control) All formulas: } \\
\text { I,96 g prot/ } 100 \text { kcal. }\end{array}$ & $\begin{array}{l}\text { - Growth } \\
\text { - General health } \\
\text { - Plasma leptin, insulin, } \\
\text { urea nitrogen, amino } \\
\text { acids }\end{array}$ & $\begin{array}{l}\text { Formula intake was similar in different groups. } \\
\text { Weight gain in the alpha-lactalbumin-enriched formula groups was } \\
\text { similar to that of the breastfed infants. The standard formula } \\
\text { group gained significantly more weight than did the breastfed } \\
\text { infants.All formula-fed infants had significantly higher plasma } \\
\text { concentrations of most essential amino acids at } 4 \text { and } 6 \text { months } \\
\text { than did the breastfed infants, and serum urea nitrogen was also } \\
\text { higher in the formula-fed infants. Insulin and leptin concentrations } \\
\text { did not differ between groups. }\end{array}$ & $\begin{array}{l}\text { B } \\
\text { No power calculation reported, compliance } \\
\text { unclear, energy intake unclear, results not } \\
\text { analysed blind, unclear about } \\
\text { between-measurments errors }\end{array}$ \\
\hline
\end{tabular}




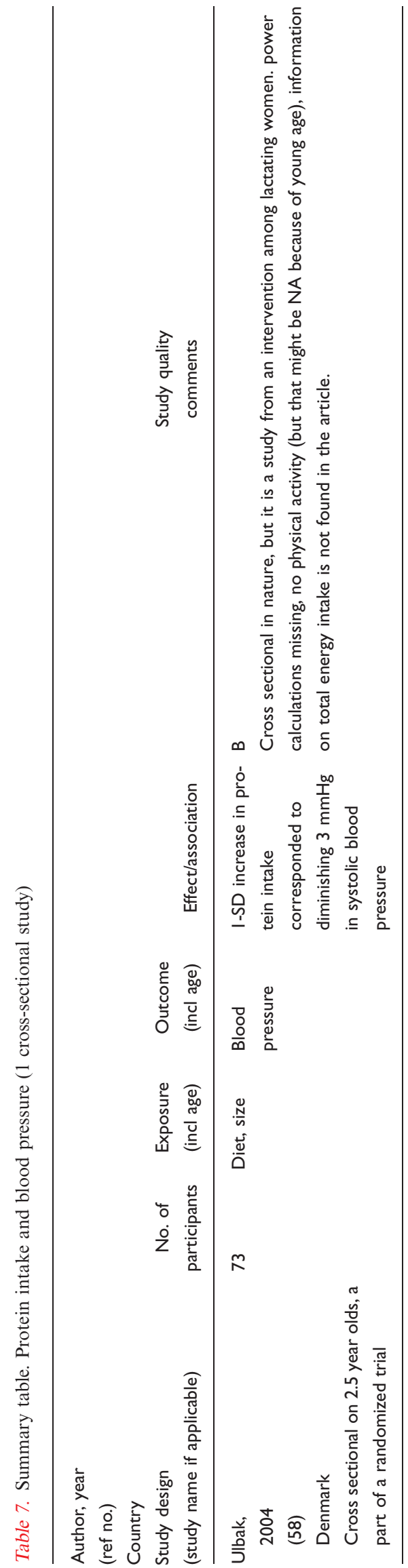

Dietary intake was assessed by 3-day weighed records during three consecutive days ( 2 weekdays and 1 weekend day) at 3, 6, 12, and 24 months. Energy intake was not calculated for food records containing any breastfeeding as breast milk intake was only measured in a subgroup. Food records with energy intake greater than three SDs of the mean by months and those deemed incomplete or with reported concurrent illness were excluded. (Note: No details given about the number of excluded records.)

Infant formula with higher protein content was associated with higher weight in the first 2 years of life but had no effect on length. At 24 months, adjusted z-score for weight-for-length in the lower protein formula group was 0.20 (95\% CI: $0.06,0.34 ; P=0.005)$ lower than in the higher protein group and did not differ from that of the breastfed reference group. The effect of intervention was not different between countries. Compared with breastfed children, those fed high-protein formula had significantly higher z-scores for weight, length, weight-for-length, and BMI at 24 months. Analyses were also performed at 3, 6, and 12 months, and in general, the differences were greatest at 12 months for weight, weight-for-length, and BMI. The authors conclude that limiting dietary protein intake during infancy might be a way to decrease the risk of overweight and obesity in later life.

Larnkjær et al. (30), graded B, performed a randomized controlled trial to study the effects of whole milk and infant formula on growth and IGF-1 from 9 to 12 months of age in Denmark. Healthy infants $(n=83)$ were randomized to receive either whole milk (WM) or infant formula (IF) and either a daily fish oil supplement or no supplement. Dietary intake was measured over seven consecutive days at 9 and 12 months using a pre-coded dietary record developed for children with portion sizes estimated from a portion size photo series. The infants in both groups consumed about $300 \mathrm{ml}$ WM or IF per day. Measurement errors in the dietary records were not considered.

No effect of milk type on growth was found in this 3month intervention study. [Note: Dropouts (17\% of WM and $6 \%$ of IF) were $1.6 \mathrm{~cm}$ shorter at 9 months, which could be problematic as this was a study on growth in infancy. Also, the breastfeeding prevalence between 9 and 12 months was lower in the IF group, although including breastfeeding in the analysis made no difference.] Intake of WM significantly increased the $\mathrm{PE} \%$; $\mathrm{PE} \%$ was 14.2 in WM and 11.4 in IF at 12 months, whereas no differences were found in weight and length between groups. The authors suggest that this could be due to the relatively short intervention period, and that there is a need for studies on the long-term effects of protein and milk protein.

Intake of WM increased sIGF-I in boys $(P=0.034)$ but not in girls. Intake of fish oil had no effect on the outcomes. Including all infants, $\mathrm{PE} \%$ was positively 
Table 8. Protein intake and neurodevelopment (2 cohort studies)

Author, year

(ref no.)

Country

Study design

(study name if No. of

applicable) participants

Exposure (incl age)

Outcome (incl age)

Study quality

Morgan, $\quad 144 \quad$ I. Total red and white meat intake (g) from Neurodevelopment was determined from Meat intake from 4 to 12 and 4 to 16 months was 2004 (37)

UK 4 to 12 months as a continuous variable, i.e. total meat intake over $2 \mathrm{I}$ days between

Scales of Infant Development II at 22

vively and significantly related to psychomotor developmental indices $(p, 0.02$ and 0.013 , respec-

2. Total red and white meat intake $(g)$ from

4 to 16 months as a continuous variable, i.e.

total meat intake over 28 days between

4 and 16 months.

3. Total red and white meat intake (g) from

4 to 24 months as a continuous variable, i.e.

total meat intake over 42 days between

4 and 24 months.

Rask-Nissilä, $\quad 496 \quad$ (Energy [kcal]; fat [E\%];

2002,

(59)

Finland

Prospective

cohort saturated, monounsaturated, and

polyunsaturated fatty acids [E\%]; protein

[E\%]; and cholesterol [mg/day]) and serum

cholesterol concentrations tively) but there was no association between

breastfeeding and psychomotor months

developmental indices nor any interaction between

meat intake and breastfeeding. Conversely,

breastfeeding was positively and significantly related

to mental developmental indices $(p=0.01)$ but there was no association between meat intake and mental

developmental indices or any interaction between

breastfeeding and meat intake. These findings

remained after adjustment for potential confounding factors.

The neurologic development (speech and High protein intake at 5 and 4 years predicted speech language skills, gross motor and language skills at 5 years of age.

Criteria for inclusion/ performance and perception)

exclusion not clear, loss to

follow-up $>50 \%$,

associations between dietary

exposures not reported,

energy adjustment not clear

confounders? 
associated with sIGF-I at both 9 and 12 months after adjusting for sex and breastfeeding. Positive correlation was also found between sIGF-I and intake of WM and WM products adjusted for sex and duration of full breastfeeding. Boys had lower levels of sIGF-I and sIGFBP-3 at 9 and 12 months than girls. The authors conclude that the results suggest that high protein intake is positively associated with sIGF-I concentration in wellnourished infants.

Räihä et al. (5), graded B, studied breastfed and formula-fed healthy term infants. Infants who stopped breastfeeding before 28 days of age were randomly assigned to receiving one of the three study formulas up to 120 days of age. The three isocaloric formulas differed by their protein source: a conventional whey adapted starter formula with a whey/casein ratio of $60 / 40$ and a protein content of $2.2 \mathrm{~g} / 100 \mathrm{kcal}$ was compared with two experimental formulas with a whey/casein ratio of 70/30 and a protein content of $1.8 \mathrm{~g} / 100 \mathrm{kcal}$.

No differences were found between the four feeding groups for weight- and length-gains or for body mass indices (BMI). No differences in energy intakes between the formula-fed groups could be found, whereas protein intakes were lower in infants fed the $1.8 \mathrm{~g} / 100 \mathrm{kcal}$ formulas. Plasma urea levels of the infants fed the $1.8 \mathrm{~g} /$ $100 \mathrm{kcal}$ formulas were closer to those found in the breastfed infants. The authors conclude that a whey predominant formula with a protein/energy ratio of $1.8 \mathrm{~g} / 100$ $\mathrm{kcal}$ provides adequate intakes of protein from birth to 4 months of age.

Sandström et al. (31), graded B, did a (partly) randomized control study on the effects on growth of exchanging part of the protein in milk-based formulas with $\alpha$-lactalbumin. All formulas contained $1.96 \mathrm{~g}$ protein/100 $\mathrm{kcal}$, but with differences in the protein composition. Breastfed infants were controls. Weight gains in the $\alpha$ lactalbumin-enriched formula groups were similar to that of the breastfed infants. The standard whey-predominant formula group gained significantly more weight than did the breastfed infants. All formula-fed infants had significantly higher plasma concentrations of most essential amino acids at 4 and 6 months than did the breastfed infants, and SUN was also higher in the formula-fed infants, which might indicate that the protein content of $\alpha$-lactalbumin-enriched formula can be further reduced.

\section{Prospective cohort studies}

Dorosty et al. (32), graded B, studied the adiposity rebound (AR) among 5-year-olds in relation to protein intake at 18 months. Dietary intake was assessed through 3-day household measured records at 18 months (records were also collected at 8 months but were not used in the present study). Measurement errors in the dietary recordings were not considered. No evidence for an association between protein intake, or any other dietary variable, and timing of the AR were found. Children with very early ( $\leq 43$ months) or early (from 49 but before 61 months) AR had parents with significantly higher BMI and were more likely to have at least one obese parent.

Gunnarsdottir et al. (3), graded B, studied BMI at 6 years in relation to size at birth, growth between 0 and 12 months, and food intake among a representative sample of Icelandic children. Dietary intake was assessed through monthly repeated 24 -h records throughout the first 12 months and 3-day weighed records at 9 and 12 months of age. The children were weighed before and after breastfeeding. Measurement error in the dietary assessment was not considered.

Weight gain from birth to 12 months as a ratio of birth weight was positively related to BMI at the age of 6 years in both genders ( $\beta 2.9 \pm 1.0, P=0.008$, and $\beta 2.0 \pm 0.9$, $P=0.032$ for boys and girls, respectively). Boys in the highest quartile of protein intake $(\mathrm{E} \%)$ at the age of 9-12 months had significantly higher BMI at 6 years than the lowest and the second lowest quartiles $(17.8 \pm 2.4$ vs. $15.6 \pm 1.0$ and $15.3 \pm 0.8, P=0.039$ and $P=0.01$, respectively). Energy intake was not different between the groups. Together, weight gain at $0-12$ months and protein intake at $9-12$ months explained $50 \%$ of the variance in BMI among 6-year-old boys. The authors concluded that rapid growth during the first year of life is associated with increased BMI at the age of 6 years in both genders. In boys, high intake of protein in infancy could also contribute to childhood obesity. (Note: Bonferroni's correction for multiple tests was used when significant differences were found.)

Günther et al. (33), graded B, studied the AR among 7year-olds in relation to protein intake between 12 and 24 months. Six repeated 3-day weighed records assessed dietary intake during the first 2 years, each covering 2 weekdays and 1 weekend day. In the present study, records from 12, 18 and 24 months were used. Measurement error in the dietary assessment was not considered, but all dietary variables were preadjusted for total energy intake using the residual method.

Girls in the highest tertile of habitual protein intake (E\% and $\mathrm{g} / \mathrm{kg}$ reference body weight $[\mathrm{RBW}] /$ day) had a significantly higher BMI SD score (BMI-SDS) at AR than those in the lower tertiles. In boys, there were no differences in BMI-SDS at AR between tertiles of habitual protein intake ( $\mathrm{E} \%$ or $\mathrm{g} / \mathrm{kg} \mathrm{RBW} / \mathrm{day})$. Boys in the lowest tertile of habitual protein intake $(\mathrm{E} \%)$ tended to experience a later AR $(P=0.07)$. But neither in girls nor in boys was age at AR significantly different between tertiles of habitual protein intake. The authors concluded that a higher habitual protein intake between the age of 12 and 24 months was associated with a higher BMI-SDS at $\mathrm{AR}$ in girls, but not in boys. There was no consistent relation between habitual protein intake in early childhood and timing of AR. 
Günther et al. (34), graded A, analyzed the associations of different protein intakes during 6-24 months with BMI and percentage body fat (\%BF) at 7 years, using data from the DONALD study in Germany. Dietary intake was assessed by 3-day weighed records during three consecutive days ( 2 weekdays and 1 weekend day) at $6,12,18$, and 24 months. Breastfed infants were weighed before and after each feed. Goldberg's cut-off and Schofield equations were used to test the validity of the dietary assessment, and the residual model was used to adjust total protein intake for energy intake and sex. The median of these energy-adjusted protein intakes was used to distinguish different patterns of low and high protein intakes, and marked differences were observed between the low and high protein groups at 6 months $(7-8 \mathrm{E} \%$ and $12 \mathrm{E} \%)$ and at 12 months (11-12 E\% and 14-15 E\%), respectively.

A consistently high protein intake at 12 and 18-24 months was independently related to a higher mean BMI SDS and \%BF at 7 years and a higher risk of having a BMI or $\% \mathrm{BF}$ above the 75 th percentile. The analyses included adjustments for a large number of possible confounders, such as dietary factors (e.g. energy intake and breastfeeding) and parental characteristics (e.g. maternal overweight). Protein intake at 6 months was not associated with the outcomes. They conclude that their results suggest an association between high protein intakes during complementary feeding and the transition to the family diet with both a higher BMI and higher body fatness at 7 years of age.

Günther et al. (35), graded A, used data from the DONALD study to examine whether there may exist a critical period of protein intake for later obesity early in childhood and to analyze the relation between protein intake from different sources on BMI and \%BF at 7 years of age. Dietary intake was assessed by 3-day weighed records during three consecutive days ( 2 weekdays and 1 weekend day) at $6,12,18,24$ months and yearly thereafter. Mean intake was calculated for the periods 18-24 months, 3-4 years, and 5-6 years. Breastfed infants were weighed before and after each feed, and $5 \%$ was added to the test weighing results to account for insensible water loss. Goldberg's cut-off and Schofield equations were used to test the validity of the dietary assessment, and the residual model was used to adjust total protein intake for energy intake and sex.

The ages of 12 months and 5-6 years were identified as critical periods at which higher total and animal, but not vegetable, protein intakes were positively related to body fatness at 7 years. Animal protein E\% at 12 months was positively associated with BMI SDS at 7 years. The analyses were adjusted for several dietary and family characteristics, such as energy and fat intake and maternal overweight. When examining different sources of protein, dairy protein $\mathrm{E} \%$ at 12 months, but not meat or cereal, showed a positive association with BMI SDS $(p=0.02)$ and $\% \mathrm{BF}$ at 7 years $(P=0.07)$. The authors conclude that a higher intake of animal protein at 12 months, especially from dairy foods, might be associated with an unfavorable body composition at 7 years, and that the age of 5-6 years might represent another critical period of protein intake for later obesity risk.

Hoppe et al. (36), graded B, studied body size (BMI), body composition (percent body fat, \%BF), and insulinlike growth factor I (sIGF-I) at 10 years of age among Danish children ( $n=142$ at 9 months, 105 at 10 years) in relation to protein intake at 9 months and SUN at 9 months and 10 years. Dietary intake was assessed through 5-day weighed records at 9 months, including three weekdays and a weekend. (Note: It is not clear if measurement errors in the dietary recordings were considered. About one third of the children were breastfed at 9 months, but there is no information about whether breast milk intake was measured or if it is included in the nutrient calculations.) Adjustments were made for breastfeeding status at 9 months without any effect. Tanner stages were assessed at 10 years but not adjusted for in the analyses (96\% of boys and 63\% of girls had no sign of pubertal development).

In total, $7.8 \%$ of boys and $7.5 \%$ of girls were overweight, none were obese. SUN (mmol/l) at 9 months was a predictor for BMI and weight at 10 years. Protein intake ( $\mathrm{E} \%, \mathrm{~g} /$ day but not $\mathrm{g} / \mathrm{kg} /$ day) at 9 months was a predictor for weight and height at 10 years. The associations remained when adjusting for parental body size, but were attenuated when adjusting for infant body size at 9 months.

Morgan et al. (37), graded B, examined body weight, length, and head circumference at 4, 8, 12, 16, 20, and 24 months in a cohort study of 144 infants. Dietary intake was measured through 7-day weighed food records at 4 , $8,12,16,20$, and 24 months (meat intake calculated as average intake during 4-24 months). Meat intake from 4 to 12 months was positively and significantly related to weight gain. This association might be mediated via protein intake but was independent of energy, zinc, or iron intake. These findings remained after adjustment for potential confounding factors. There was no interaction between meat intake and breastfeeding on growth.

Öhlund et al. (4), graded B, did a follow-up at 4 years of age of healthy children (63 girls and 64 boys) previously followed prospectively from 6 to 18 months of age. Monthly 5-day weighed records measured dietary intake at 6-18 months and at 4 years. BMI at 6-18 months was a strong predictor of BMI at 4 years. Intake of protein in particular, and also of total energy and carbohydrates at $17 / 18$ months and at 4 years, was positively associated with BMI at 4 years. Although BMI at 6-18 months was the strongest predictor of BMI at 4 years, in the final multivariate models of the child's 
BMI, high protein intake at $17-18$ months and at 4 years, energy intake at 4 years, and the father's, but not the mother's, BMI were also independent contributing factors. One limitation of the study was that physical activity was not included as a factor when estimating energy requirements.

Scaglioni et al. (38), graded B, studied growth of healthy children (singleton birth, healthy parents) from birth to age 5 years. Dietary intake was assessed at 1 and 5 years-of-age through age-adjusted food frequency questionnaires (FFQs) complemented by a $24-\mathrm{h}$ recall to standardize the usual serving size. Measurement error in the dietary assessment was not considered. The prevalence of overweight at the age of 5 years was strongly associated with parental overweight $(P<0.0001)$, and overweight children had a higher intake of protein at the age of 1 year than non-overweight children $(22 \mathrm{E} \%$ vs. $20 \mathrm{E} \%$, $P=0.024)$. In children born from overweight mothers, the prevalence of overweight at the age of 5 years tended to be higher in bottle-fed than in breastfed ones $(62.5 \%$ vs. $23.3 \%, P=0.08)$. The authors concluded that parental overweight is a major risk factor for childhood overweight in the first years of life, but an early high protein intake may also influence the development of adiposity.

Skinner et al. (39), graded B, found in a prospective study of 70 children that their BMI at 8 years was negatively predicted by age of AR and positively predicted by their BMI at 2 years. Dietary intake was assessed through nine sets of non-consecutive 3-day data collections (2 days' recordings and one 24-h recall). Measurement error in the dietary assessment was not considered. Longitudinal intake (between 2 and 8 years) of protein and fat (grams/day and $\mathrm{E} \%$ ) were positively related to BMI at 8 years, but mean carbohydrate intake over the same time period was negatively related to BMI at 8 years. A weakness, also mentioned by the authors, was that there were no observations to verify normal food intake nor was total energy expenditure measured by doubly-labelled water (DLW) methods.

Van Vught et al. (40), graded B, studied associations between intakes of total protein as well as the amino acids arginine (ARG) and lysine (LYS) in the habitual diets of normal weight and overweight 6-year-olds and subsequent linear growth, body fat, and fat free mass (FFM) at 9 years. Dietary intake was assessed through a 7-day estimated food record. Reporting of dietary intake was evaluated by comparing reported energy intake with estimated energy requirements. Children reporting an energy intake below BMR $\times 1.3$ or above $\mathrm{BMR} \times 2.0$ were excluded.

High ARG intake was associated with linear growth among girls. Furthermore, in girls, fat mass index (FMI) had a stronger inverse association with high ARG intake, if it was combined with high LYS intake, instead of low LYS intake $(P=0.03)$. No associations were found in boys although the change was in the same direction as for the girls. The authors conclude that in pre-pubertal girls, linear growth may be influenced by habitual ARG intake, and body fat gain may be relatively prevented over time by the intake of the amino acids ARG and LYS.

In another study, Van Vught et al. (41), graded B, studied associations between intakes of protein, ARG, and LYS among 8-10-year-olds and subsequent 6-year change in body composition (fat-free mass index [FFMI] and FMI). Dietary intake was assessed through one 24-h recall.

Note: Measurement errors were discussed but not measured. The authors suggest that among lean girls, high protein intakes at 8-10 years may decrease subsequent body fat gain and increase fat free mass gain depending on the available amounts and combinations of ARG and LYS.

\section{Cross-sectional studies}

Budek et al. (14), graded B, studied concentrations of serum insulin-like growth factors (sIGF-I) in relation to intake of total dairy and meat protein in pre-pubertal 8year-old boys. Dietary intake was assessed using a 3-day weighed food record ( 2 weekdays and 1 weekend day). Measurement errors in the dietary recordings were not considered, but all dietary variables were preadjusted for total energy intake using the residual method. Free sIGFI was positively associated with total protein $(p<0.01)$ and dairy protein $(p=0.06)$ but not with meat protein. (Note: Meat protein included red meat, poultry, and fish, but not pork. Plant protein was estimated from the difference between total protein intake and intake from dairy, meat, and egg.) Measurement errors in the dietary recordings were not considered, except for mentioning that dietary assessment in children is difficult.

Hoppe et al. (13), graded B, examined associations between protein intake, sIGF-I concentrations, and height in a cross-sectional study of 2.5 -year-old healthy children $(\mathrm{n}=90)$ in Denmark. Dietary intake was reported through a 7-day estimated food record with pre-coded response categories. Amounts were given as household measures or as standard portion sizes estimated from a picture booklet. Measurement errors in the dietary recordings were not considered. The 10th, 50th, and 90th percentiles of protein intake were 2.4, 2.9, and $4.0 \mathrm{~g} / \mathrm{kg} / \mathrm{day}$, respectively; $63 \%$ was animal protein.

In multiple linear regressions with adjustment for sex and weight, height and sIGF-I concentration were positively associated with each other as well as with intakes of animal protein ( $\mathrm{g} /$ day) and milk but not with those of vegetable protein or meat. The authors concluded that milk intake was positively associated with sIGF-I concentrations and height. An increase in milk intake from 200 to $600 \mathrm{ml} /$ day corresponded to a $30 \%$ increase in circulating sIGF-I. The authors suggest that milk 
compounds have a stimulating effect on sIGF-I concentrations and, thereby, on growth.

Kourlaba et al. (42), graded B, studied interaction effects between energy and macronutrient intakes and angiotensin-converting enzyme 1 (ACE) I/D polymorphism on adiposity-related phenotypes among $1-5$-year-olds in the Greek Genesis study. Dietary intake was assessed through 3-day records (2 weekdays and 1 weekend day) combining weighed food records (by staff during nursery hours) and 24-h recall. Measurement errors in the dietary recordings were discussed but not measured.

Significant interactions were found between the $A C E \mathrm{I} /$ $\mathrm{D}$ polymorphism and protein intake on BMI and being overweight. Stratified analyses revealed that protein intake was associated with BMI and being overweight only among carriers of the D-allele (i.e. DD or ID genotypes). Protein intake was higher among those 'at risk of being overweight' or 'overweight' compared with their normal-weight counterparts. The authors conclude that the results suggest that the $A C E \mathrm{I} / \mathrm{D}$ polymorphism may act as a modifying factor in the response of adiposity-related phenotypes to diet and that further research is required to confirm their findings.

Maillard et al. (43), graded B, studied growth in relation to dietary intake among 5-11-year-old non-obese pre-pubertal children. Dietary intake was assessed through 1-day records, that is, one out-of-school-weekday. Intake data were validated with Schofield's equation and Goldberg's \& Black's cut-off. They found that associations between adiposity and protein intake as $\mathrm{E} \%$ or energy intake were non-significant. All adiposity indices (except waist girth and BMI) were significantly and inversely associated in girls with energy intake from carbohydrates (\%EIC, all $P$-values $<0.02$ ), and positively with energy intake from fat ( $\% \mathrm{EIF}$, all $P$-values $<0.05)$. Similar but non-significant trends were observed in boys. The relationships were not linear, and thresholds close to current dietary recommendations were highlighted.

Manios et al. (44), graded B, studied anthropometrical indices in relation to nutrient intake (based on 3-day food records; 2 weekdays, 1 weekend day) among children aged 1-5 years. Intake data were validated with Schofield's equation and Goldberg's \& Black's cut-off. Bonferroni correction was used. For both fat and carbohydrate, a substantial percentage of toddlers and preschoolers had usual intakes outside the acceptable macronutrient distribution range, whereas protein was less than this range.

No statistically significant differences were seen in protein $\mathrm{E} \%$ between children with normal weight $(17.1 \pm 1.6)$, at risk of overweight $(17.1 \pm 1.5)$, or overweight $(17.1 \pm 1.5)$. However, children 'at risk of overweight' and 'overweight' had higher intake of total energy, protein $(\mathrm{g} / \mathrm{day})$, and fat $(\mathrm{g} / \mathrm{day})$ compared with their normal-weight counterparts $(p<0.001$ for all), whereas no differences were found for micronutrient intakes.

Complementary search

Closa-Monasterolo et al. (45), graded B, aimed to investigate whether sex modulates the responses of relevant biochemical parameters and growth to different protein intakes early in life. In randomized controlled trials (RCT) in five European countries [the same participants as in (29)], formula-fed infants were assigned to receive formula with lower or higher protein content (cow-milk-based infant formula with 1.77 or $2.9 \mathrm{~g}$ protein $/ 100 \mathrm{kcal}$ ) from a median age of 14 days. The protein content represented approximately the lowest and highest acceptable levels in the range given in the EU directives from 1991.

Protein (g/day) and energy intake (kcal/day) was assessed by 3-day weighed records during three consecutive days (2 weekdays and 1 weekend day) at 3 and 6 months. Measurement errors in the dietary recordings were not considered. Outcomes (e.g. sIGF-I axis parameters, weight, length, BMI, and leptin) were measured at 6 months. The authors conclude that their findings indicate that the endocrine response to a high protein diet early in life may be modulated by sex. The sIGF-I axis of female infants showed a stronger response to the intervention, but there was no enhanced effect on growth.

\section{Conclusion}

BMI/growth. Thirteen studies (one CT, nine cohort, three cross-sectional) found an association between higher protein intake in different age groups and increased growth/higher BMI; of the 13 studies, 1 study concluded that the combinations of amino acids in infant formula matters, while 4 studies (two CT, one cohort, and one cross-sectional) saw no effect although one of them saw a positive association with the intake of certain amino acids (Table 2).

In an intervention study, Koletzko et al. (29) found that a higher protein content of infant formula was associated with higher weight in the first 2 years of life but had no effect on length compared with infants fed a low-protein formula. Compared with breastfed children, those fed high-protein formula had significantly higher z-scores for weight, length, weight-for-length, and BMI at 24 months.

Intake during the first year and outcomes between 5 and 10 years of age was studied in three cohort studies. Gunnarsdottir et al. (3) found an association between high intake of protein in infancy and increased risk for childhood obesity at 6 years only among boys, while rapid growth during the first year of life was associated with increased BMI at the age of 6 years in both genders. Scaglioni et al. (38) found a positive association between protein intake at 1 year and the risk of overweight at 5 years, although they conclude that parental overweight is 
a major risk factor for childhood overweight in the first years of life. Hoppe et al. (36) found that protein intake ( $\%$ and $\mathrm{g} /$ day, but not $\mathrm{g} / \mathrm{kg} / \mathrm{day}$ ) at 9 months was a predictor for weight and height at 10 years.

Three cohort studies looked at protein intake in early childhood and outcomes at 4-10 years. Öhlund et al. (4) found that BMI at 6-18 months was the strongest predictor of BMI at 4 years, but protein intake at $17-18$ months and at 4 years, energy intake at 4 years and the father's, but not the mother's, BMI were also independent contributing factors. Günther et al. (34) found that consistent high protein intake at 12 and 18-24 months, but not 6 months, was positively related to a higher mean BMI SDS (SD score) at 7 years and a higher risk of having a BMI above the 75th percentile. Skinner et al. (39) found that mean protein and fat intakes recorded between 2 and 8 years were positive predictors of BMI at 8 years.

Four studies, that is, one CT, two cohort and one crosssectional, focused on the effects of different kinds of amino acids and protein. In an intervention study, Sandström et al. (31) found that weight gains in groups fed $\alpha$-lactalbumin-enriched formula were similar to that of the breastfed infants, while infants fed the standard formula gained significantly more weight than did the breastfed infants. Morgan et al. (37) concluded that meat intake from 4 to 12 months was positively and significantly related to weight gain during the first 2 years; further analysis suggested this association might be mediated via protein intake but was independent of energy, zinc or iron intake. In contrast, Günther et al. (35) found that dairy protein $\mathrm{E} \%$ at 12 months, but not meat or cereal, showed a positive association with BMI SDS a 7 years. In a cross-sectional study, Hoppe et al. (13) showed that height $(\mathrm{cm})$ at 2.5 years was positively associated with intakes (g/day) of animal protein and milk, but not with intakes of vegetable protein and meat.

Two cross-sectional studies found that the intake of protein (42), and energy, protein, and fat (44), was higher among those 'at risk of being overweight' or 'overweight' compared with their normal-weight counterparts.

Four studies, that is, two CT, one cohort and one crosssectional, found no association between protein intake and growth. The cross-sectional study by Maillard et al. (43) found no effect of protein intake on growth (several different indices) among 5 to 11-year-old pre-pubertal children, but inverse association with energy intake from carbohydrates and positive associations with energy intake from fat. These associations were significant for girls and similar but non-significant trends were observed in boys. The intervention study by Larnkjær et al. (30) found no effect of milk type (whole milk or infant formula) on growth between 9 and 12 months. However, drop-outs (17\% of whole milk and $6 \%$ of infant formula) were $1.6 \mathrm{~cm}$ shorter at 9 months, which might have affected the results. The second intervention study, by Räihä et al. (5), found no difference in BMI or weightand length-gains between four feeding groups (breastfed vs. formula-fed with different protein content and ratio whey/casein) during the first 120 days. One study from Van Vught (40) found no association between protein intake and growth for either sex although they found a positive association between the amino acid ARG and linear growth. In addition, the study found in the complementary search (45) found no enhanced effect on growth from increased protein intake in infancy.

Adiposity rebound (AR). Two cohort studies found no association between protein intake and timing of AR. Dorosty et al. (32) found no evidence for an association between protein intake at 18 months, or any other dietary variable, and timing of the AR. Günther et al. (33) did not find any consistent relation between habitual protein intake in early childhood and timing of AR either, but concluded that a higher habitual protein intake between the age of 12 and 24 months was associated with a higher BMI-SDS at AR in girls, but not in boys.

Body composition. Two A-graded cohort studies from the same group $(34,35)$ found a positive association between protein intake and $\% \mathrm{BF}$, while two studies from another group $(40,41)$ found inverse associations between protein intake and FMI among lean girls. Günther et al. (34) found that consistently high protein intake at the ages of 12 and 18-24 months, but not 6 months, was positively related to a higher mean $\% \mathrm{BF}$ at 7 years and a higher risk of having a $\% \mathrm{BF}$ above the 75 th percentile. In another study, they identified the ages of 12 months and 5-6 years as critical periods at which higher total and animal (especially from dairy), but not vegetable, protein intakes were positively related to body fatness at 7 years (35).

Van Vught et al. (40) conclude that in pre-pubertal girls, body fat gain may be prevented over time by the intake of the ARG and LYS. In another study (41), among lean girls in 3rd-9th grade, they found inverse associations between intake of protein as well as of ARG and LYS and change in FMI.

Based on a cross-sectional study, Kourlaba et al. (42) suggest that responses to diet of different adiposityrelated phenotypes may be modified by $A C E$ I/D polymorphism (but they also state that further research is required to confirm their findings).

sIGF-I. Five studies (four from the same group, but with different children) found positive associations between milk intake and concentrations of sIGF-I. In a cross-sectional study, Hoppe et al. (13) found that milk intake was positively associated with sIGF-I concentrations and height among 2.5-year-old boys and girls. The 
same group conducted a short 7-day intervention study among 8 -year-old boys $(n=24)$ and found that high intake of milk, and not meat, increased concentrations of sIGF-I and sIGF-I/sIGFBP-3 (28). In another crosssectional study among 8-year-old boys (14), the same group found that free sIGF-I was positively associated with total protein $(p<0.01)$ and dairy protein $(p=0.06)$ but not with meat protein. In a later, and larger 7-day intervention study on boys $(n=57)(27)$, they concluded that casein stimulates circulating sIGF-I and that both milk protein fractions (whey and casein) seemed to be important, but different, in the growth-stimulating effect of milk. In a randomized trial between 9 and 12 months of age, Larnkjær et al. (30) found that whole milk, but not infant formula, increased sIGF-I in boys, but not in girls. They also found that high protein intake $(\mathrm{E} \%)$ was positively associated with sIGF-I concentration in both boys and girls. The results found in the complementary search (45) indicated that the endocrine response to a high protein diet early in life may be modulated by sex.

Based on the above, we conclude that evidence is convincing (grade 1) that higher protein intake in infancy and early childhood is associated with increased growth and higher BMI in childhood. There is limited-suggestive evidence (grade 3 ) that the intake of animal protein, especially from dairy, has a stronger association with growth than vegetable protein has. The association found between higher intake of milk and increased levels of sIGF-I strengthens this finding.

There is limited-inconclusive evidence (grade 4) that protein intake is related to timing of AR. Due to a scarcity of strong studies, there is also limited-inconclusive evidence (grade 4) that protein intake in later childhood is associated with later BMI. The evidence is also limited-inconclusive (grade 4) (due to the two Agraded studies not being independent) that there is an association between higher protein intake in early childhood and later body fat increases. There might also be different effects depending on BMI, phenotypes, and gender. This conclusion is supported by the randomized trial on endocrine responses to high protein diets in infancy found in the complementary search (45), although it is not enough to change the grading of the evidence.

\section{Bone health}

Table 4 shows a summary of studies with outcome bone health (details are provided in appendix 4). In total, six papers, all graded $\mathrm{B}$, were chosen in the systematic review process to be evaluated for the evidence of an association between protein intake and bone health. Of those six, one was a clinical trial, two were prospective cohort studies, and three were cross-sectional studies. Four studies came from the same research group. (One additional study was graded $\mathrm{C}$ and therefore excluded).

Clinical trials

Budek et al. (46), graded B, compared the short-term (7 days) effect of high milk and high meat intake on bone turnover during pre-puberty among 24 Danish boys aged 8 years assigned to either 1.51 milk per day or $250 \mathrm{~g}$ meat per day (both containing $53 \mathrm{~g}$ protein) given together with the habitual diet for 7 days. The participants all had a habitual milk intake of at least $500 \mathrm{ml} /$ day before the start of the study. Dietary intake was assessed using two repeated 3-day weighed food records (2 weekdays and 1 weekend day); the first kept before the intervention (days -3 to 0 ) and the second at the end of the intervention (days 5 to 7). Measurement errors in the dietary recordings were not considered, but the importance of maintaining usual dietary intake was emphasized to the families.

There were no significant differences between the groups' intake of total energy (MJ/day) or protein ( $\mathrm{g} /$ day, $\mathrm{g} / \mathrm{kg} /$ day) neither before nor after the intervention. In the milk group, the proportion of energy from carbohydrates increased slightly and the proportion from fat decreased with an average 8\%-units (from $34.6 \mathrm{E} \%$ to $26.7 \mathrm{E} \%$ ), while the meat group decreased the proportion of energy from carbohydrates with on average $10 \%$-units (from 56.6 to $46.8 \mathrm{E} \%$ ) and increased the proportion from fat with about $2 \%$-units.

At equal protein intake, milk, but not meat, decreased markers for bone formation and resorption after 7 days. The authors suggest that this effect was more likely due to some milk-derived compounds, rather than to the total protein intake. The milk group also had significantly higher calcium intake compared with the meat group and this could affect the decline observed in bone turnover in the milk group. Whether the decline in bone turnover markers promotes higher bone mineral accretion during growth needs to be further studied according to the authors.

Prospective cohort studies

Alexy et al. (47), graded B, examined the association of long-term protein intake and dietary potential renal acid load (PRAL) with bone variables in a subgroup of 229 children and adolescents (6-18 years) in the DONALD study. Proximal forearm was measured once (crosssectionally) at 6-18 years of age, and dietary intake was measured through yearly 3-day weighed records over the 4-year period prior to bone measurements. Goldberg's cut-off and Schofield equations were used to test the validity of the dietary assessment (38\% had non-valid records and were excluded). Collinearity diagnostics 
detected no evidence for collinearity between the dietary factors.

Reported protein intake measured as g/day was significantly lower in prepubescent boys and girls compared with pubescent boys and girls, while the intake measured as $\mathrm{g} / \mathrm{kg} /$ day was higher in the younger children. Long-term protein intake was positively associated with all bone variables (periosteal circumference, cortical area (CA), bone mineral content (BMC), and polar strength strain index at the proximal diaphyseal radius) in these healthy children and adolescents, also after adjustment for age, sex, and energy intake, and control for forearm muscularity, BMI, growth velocity, and pubertal development. Children with a higher dietary PRAL (i.e. indicating an inadequate intake of alkalizing minerals from vegetables and fruit) had significantly less CA and BMC. Calcium intake had no significant effect on any bone variable. The authors emphasize the importance of evaluating the whole diet when studying dietary influence on bone health.

Bounds et al. (48), graded B, studied total BMC (g) and bone mineral density (BMD, $\mathrm{g} / \mathrm{cm}^{2}$ ) measured by dual energy X-ray absorptiometry (DEXA) scan at 8 years among 52 children ( 25 boys, 27 girls) in relation to an averaged longitudinal nutrient intake between 2 and 8 years (measured as average of 3 days [2 days with estimated food records and one 24-h recall] times nine occasions). Measurement errors in the dietary recordings were not considered, but it is stated that the parents received training from registered dieticians. Mothers' BMC was also assessed by DEXA and the time children spent in sedentary activities was assessed through a questionnaire at 6 and 7 years of age. Multivariate models predicting children's total BMC and BMD at 8 years of age were developed using stepwise regression procedures adding all potentially independent variables.

Factors positively related to children's BMC at age 8 years in the final models included longitudinal intakes (ages 2 to 8 years) of protein, phosphorus, vitamin $\mathrm{K}$, magnesium, zinc, energy, and iron; height; weight; and age. Factors positively related to children's BMD at age 8 years included longitudinal intakes of protein and magnesium. Female sex was negatively associated with both BMC and BMD at age 8 years in contrast with previous studies, that have been unable to find sex differences in pre-pubertal children. Children's bone mineral indexes at ages 6 and 8 years were strongly correlated $(r=0.86, \quad P<0.0001$ for $\mathrm{BMC} ; \quad r=0.92$, $P<0.0001$ for BMD).

Cross-sectional studies

Budek et al. (49), graded B, studied BMC and bone area (BA) determined by DEXA, in relation to milk and meat protein intake at 17 years. Dietary intake was reported through a 7-day estimated food record with pre-coded response categories, supplemented with open-ended alternatives. Physical activity level was recorded using a 24-h recall questionnaire, assessing total hours per day spent at four different activity levels. Time spent on high activity level was used in the statistical analyses.

Total protein intake $(\sim 1.2 \mathrm{~g} / \mathrm{kg})$ and milk protein intake $(\sim 0.3 \mathrm{~g} / \mathrm{kg})$, but not meat protein intake $(\sim 0.4 \mathrm{~g} /$ $\mathrm{kg}$ ), was positively associated with size-adjusted BMC. The positive association between milk protein intake and size-adjusted BMC remained significant after correction for energy, calcium, and physical activity and did not seem to be mediated via current serum sIGF-I. None of the analyzed protein sources were significantly associated with size-adjusted BA. The authors suggest that some components of milk protein may promote bone mineralization.

Note: Measurement errors in the dietary recordings were not considered, except for mentioning in the discussion that the dietary assessment might include bias due to inadequate recording (however, no details are given). Pubertal stages were not considered.

Budek et al. (14), graded B, also studied concentrations of sIGF-I and markers for bone-turnover (serum osteocalcin [sOC], bone-specific alkaline phosphatase [sBAP], and $\mathrm{C}$-terminal telopeptides of type 1 collagen [sCTX]) in relation to intake of total dairy and meat protein in prepubertal 8-year-old boys. Dietary intake was assessed using a 3-day weighed food record (2 weekdays and 1 weekend day). Measurement errors in the dietary recordings were not considered, except for mentioning that dietary assessment in children is difficult. All dietary variables were preadjusted for total energy intake using the residual method. Note: Meat protein included red meat, poultry, and fish, but not pork. Plant protein was estimated from the difference between total protein intake and intake from dairy, meat, and egg.

Dairy protein was negatively associated with sOC but not significantly associated with sBAP and sCTX. Further analyses showed that dairy protein decreased sOC at a high meat protein intake $(>0.8 \mathrm{~g} / \mathrm{kg})$, whereas meat protein increased $\mathrm{sOC}$ at a low dairy protein intake $(<0.4 \mathrm{~g} / \mathrm{kg})$. Total and meat protein intake was positively associated with sBAP but not significantly associated with sOC and sCTX. Free sIGF-I was positively associated with total and dairy $(P=0.06)$ protein but not with meat protein. The authors suggest that their results indicate that dairy and meat protein may exhibit a distinct regulatory effect on different markers for bone turnover.

Hoppe et al. (50), graded B, studied associations between dietary factors and whole body BMC and BA determined by DEXA in a cross-sectional analysis of 105 10-year-old Danish children. Dietary intake was reported through a 7-day estimated food record with pre-coded 
response categories, supplemented with open-ended alternatives. Goldberg's cutoff was used to test the validity of the dietary assessment, and no implausibly low energy intakes were reported.

The mean intakes of calcium, protein, phosphorus, and sodium were $1226 \mathrm{mg}, 78 \mathrm{~g}, 1523 \mathrm{mg}$, and $3.3 \mathrm{~g}$, respectively, all considerably higher than the Nordic recommendations. In bivariate analyses, BMC and BA were positively correlated with height and weight and with intakes of energy and several nutrients. In multivariate analyses, size-adjusted BMC was positively associated with calcium intake, and size-adjusted BA was positively associated with dietary protein, and negatively associated with intakes of sodium and phosphorus. Inclusion of pubertal stages in the multiple linear regressions did not alter the outcome.

\section{Complementary search}

Libuda et al. (51), graded B, examined as part of the DONALD cohort study, the effects of nutrients (e.g. protein, calcium, and vitamin D) on bone parameters and compared their effects sizes with those of two known predictors of bone development: bone-related muscle mass and androgen levels. Long-term nutrient intakes were assessed by 3-day weighed dietary records and calculated as the mean of each dietary record in the 4 years before measurement of bone and muscle variables, for example, diaphyseal BMC, CA, and muscle area.

Of all considered nutrients, only protein showed a trend for an association with BMC $(\beta=+0.11$; $P=0.073)$ and CA $(\beta=+0.11 ; P=0.056)$. None of the other dietary variables was associated with the bone parameters. The size of the bone anabolic effect of protein was partly comparable with that of androstenediol. The authors conclude that their results suggest that bone-related muscle area has the strongest effect on bone status of healthy prepubertal children followed by the sex steroid androstenediol and protein intake, which was found to be the strongest dietary predictor of diaphyseal bone.

Mark et al. (52), graded B, is a continued analysis of the data from the intervention study by Hoppe et al. (27), studying the effects of milk-derived compounds on bone formation and resorption during growth in a 7-day randomized double-blind study among 8-year-old Danish boys with a habitual milk intake not exceeding $500 \mathrm{ml} /$ day. Markers for bone-turnover (serum osteocalcin [s-OC], bone-specific alkaline phosphatase [s-BAP], and C-terminal telopeptides of type 1 collagen [s-CTX]) were measured. The boys received one of four milk drinks, that is, whey protein with low or high content of minerals or casein protein with low or high content of minerals. The amount of whey and casein was identical to the content in 1.51 of milk. Dietary intake was assessed using two repeated 3-day weighed food records (2 weekdays and
1 weekend day); the first kept before the intervention (days -3 to 0 ) and the second at the end of the intervention (days 5 to 7). Measurement errors in the dietary recordings were not considered, but the importance of maintaining usual dietary intake was emphasized to the families.

The intake of milk drinks containing whey protein increased sOC at the low content of milk minerals, whereas it decreased sOC at the high content of milk minerals $(P<0.05)$. In contrast, the intake of milk drinks with casein protein increased sOC both at low and high content of milk minerals. They concluded that whey and casein differently affected sOC in 8-year-old boys depending on the content of milk minerals, but that it did not seem to affect other markers for bone turnover.

\section{Conclusion}

Five studies, $(14,47-50)$, report a positive association between total protein intake and BMC and/or other bone variables in childhood and adolescence. The short-term intervention study by Budek et al. (46) conclude that at equal protein intake, milk, but not meat, decreased markers for bone formation and resorption after 7 days. Three of the six studies were performed in 8-year-olds, one in 10-year-olds, and one in 6-18-year-olds, both adjusting for pubertal stage, and one in 17-year-olds not adjusting for pubertal stage. Only two of the six studies considered the validity of the dietary assessment.

Based on the above, we conclude that evidence is limited-suggestive (grade 3) for a positive association between total protein intake and $\mathrm{BMC}$ and/or other bone variables in childhood and adolescence. The two papers found in the complementary search support this conclusion, although we do not consider it enough to change the evidence grading.

\section{Puberty}

Table 5 shows a summary of studies with outcome puberty (details are provided in appendix 5). In total, four papers were chosen in the systematic review process to be evaluated for the evidence of an association between protein intake and puberty. All four papers were prospective cohort studies, of which three (one A-graded and two B-graded) originated from the same study (DONALD). The fourth study was graded B.

Prospective cohort studies

Berkey et al. (53), graded B, studied the relation of childhood diet and body size to menarche and adolescent growth in a longitudinal study of 67 Caucasian girls in Boston, United States. Data were collected prospectively from birth to 18 years during the 1930s-40s. Dietary intake was assessed through dietary history interviews every 6 months up to 11 years of age, and annually thereafter. The reliability of total protein intake was 
estimated to be $71 \%$, and the validity was tested by correlation between reported daily protein intake and the child's rate of growth of muscle in the lower leg.

They found that age at menarche, age at peak height growth velocity and peak height growth velocity were all associated with diet and body size earlier in childhood. For peak growth velocity, the same three factors emerged in all age periods, that is, more calories, more animal protein, and lower BMI were consistently associated with higher peak growth velocity (factors closer to puberty more important). Timing of puberty (age at menarche and age at peak growth velocity) was predicted by protein intake and height. Girls with higher animal protein (energy adjusted) intake and less vegetable protein at 3-5 years had earlier menarche. Higher dietary fat intake at 1-2 years was associated with earlier peak growth, and higher calorie intake at 1-2 years gave higher peak height velocity. Girls with higher animal protein intake at 6-8 years had earlier peak growth. Later age at menarche was associated with lower age at peak growth $(r=0.81$, $p<0.05)$ and lower peak growth velocity $(r=-0.41$, $p<0.05)$.

Günther et al. (54), graded A, used data from the DONALD study in Germany to examine the association between dietary protein intake in early- and mid-childhood and timing of puberty; the ages of take-off of the pubertal growth spurt (ATO), age at peak height velocity (APHV), and menarche in girls/voice break in boys. Dietary assessment method is described in Günther et al. (35) BMI, growth, body composition, and sIGF-I above.

Higher animal protein intake (E\%) at 5-6 years was associated with earlier puberty. Similar tendency was seen at 3-4 years. Vegetable protein intake was associated with a later ATO. Children with higher animal protein intake at 3-4 and 5-6 years had earlier APHV, while those with high vegetable protein intake had later APHV. Higher animal protein intake (especially milk) at 3-4 years tended $(p=0.06)$ to be, and at 5-6 years was $(p=0.02)$, associated with earlier menarche/voice break and later for high vegetable protein intake. Adjustment for confounders did not change all of these associations.

The authors conclude that whereas higher animal protein intake at 5-6 years might be related to an earlier ATO, APHV and menarche/voice break, higher intakes of vegetable protein at 3-4 and 5-6 years were associated with delayed puberty.

Remer et al. (55), graded B, investigated as part of the DONALD-study the associations between adrenal androgen (AA) secretion with early and late pubertal markers in a prospective study of 109 Caucasian children. Urine samples were used to measure urinary steroid profile, which was used to determine total AA secretion. Energy and animal protein intake was estimated from 3-day weighed dietary records 1 and 2 years before puberty onset.

AA predicted earlier ages at Tanner stage 2 for pubic hair and breast and genital development, but this was independent of protein intake. Intake of animal protein was independently negatively associated with the ATO and with the APHV and negative association of borderline significance was seen between animal protein intake and age at menarche in girls and voice break in boys. Therefore, the authors concluded that animal protein intake might be involved in earlier pubertal growth.

A paper by Shi et al. (56), graded B, was also based on the DONALD-study and included 137 healthy prepubertal 3-12-year-old children. The aim was to investigate if adrenal androgen (AA) production in childhood is associated with body composition and dietary intakes. Diet was, as in the prior study, tested by 3-days' dietary registration and urine samples were used to measure urinary steroid profile, which was used to determine total AA secretion. Fat mass (FM) predicted most of the variation in AA $(5 \%, p<0.0001)$ and total protein intake to some extent $(1 \%, p<0.05)$. The authors concluded that body fat may relevantly influence the prepubertal adrenarchal androgen status and animal protein may also make a contribution.

Complementary search

Rogers et al. (57) graded B, investigated as part of the ALSPAC study, associations between diet at three time points in childhood (3, 7 and 10 years) and age at menarche (AAM). AAM was categorized as before or after 12 years and 8 months, a point close to the median age in this cohort of British girls. Diet was assessed by FFQ at 3 and 7 years and by a 3-days' un-weighed food diary at 10 years.

Total and animal protein intakes at 3 and 7 years were positively associated with AAM $\leq 12$ years and 8 months. Meat intake at 3 and 7 years was also strongly positively associated with reaching menarche by 12 years and 8 months. The authors concluded that their data suggest that higher intakes of protein and meat in early to mid-childhood may lead to earlier menarche. Note: energy intake at 3 and 7 years is not stated and thus is not possible to deem as credible or not.

\section{Conclusion}

Three studies, one American study from the 1930-40s and two from the German DONALD-study found an association between increased intake of animal protein in early childhood (around 5-6 years) and earlier puberty. The third paper from the DONALD-study looked at prepubertal hormone levels and concluded that body fat and animal protein intake may increase the hormone levels. 
Based on the fact that three of the papers of the original search came from the same group, we first concluded that evidence was slightly too weak to grade it as probable that increased intake of animal protein in childhood is related to earlier puberty, but as the paper found in the complementary search support this conclusion, we judge that the evidence grade increases to probable (grade 2).

\section{Glucose-insulin metabolism}

Table 6 shows a summary of two randomized control studies (both graded B) looking at glucose-insulin metabolism (details are provided in appendix 6).

\section{Clinical trials}

Hoppe et al. (27) graded B, examined in a double-blinded randomized trial the effects of the two major milk fractions, whey and casein, and milk minerals $(\mathrm{Ca}$ and P) on sIGF-I and glucose-insulin metabolism (details about the methodology BMI, growth, body composition, and sIGF-I). Average daily protein intake was increased by $17 \%$ by the whey drink and by $51 \%$ by the casein drink. In the whey group, fasting insulin increased by $21 \%$. No independent effects of a high milk mineral intake on insulin were found.

Increase in SUN was significantly higher in the caseingroup than in the whey group. Conversely, whey increased fasting insulin more than did casein. A limitation of the study, also mentioned by the authors, is that the subjects were allowed to eat their habitual diet, so there might be other factors in the diet contributing to the findings. However, the authors point out that this has been controlled for in the analyses. The results were not changed markedly after controlling for energy intake, protein intake, SUN or milk intake. The authors concluded that whey protein stimulates fasting insulin.

Sandström et al. (31) graded B, did a randomized control study on the effects of exchanging part of the protein in milk-based formulas with $\alpha$-lactalbumin on insulin levels (and other outcomes). All formulas contained $1.96 \mathrm{~g}$ protein $/ 100 \mathrm{kcal}$, but with differences in the protein composition.

Three different formulas were used; 1) wheypredominant standard infant formula $(11 \% \alpha$-lactalbumin, $14 \%$ glycomacropeptide [GMP]); 2) $\alpha$-lactalbumin -enriched formula ( $25 \% \alpha$-lactalbumin), with GMP accounting for $15 \%$ of the protein content and 3) $\alpha$ lactalbumin-enriched formula ( $25 \% \alpha$-lactalbumin), with GMP accounting for $10 \%$ of the protein content. Breastfed infants were the controls. Measurement errors in the dietary recordings were not considered.

All formula-fed infants had significantly higher plasma concentrations of most essential amino acids at 4 and 6 months than did the breastfed infants, and SUN was also higher in the formula-fed infants. Insulin and leptin concentrations did not differ between groups.

\section{Conclusion}

Based on the low number of studies, we conclude that evidence is limited-inconclusive (grade 4) that milk protein fractions are related to glucose-insulin metabolism in infancy and childhood.

\section{Blood pressure}

Table 7 shows a summary of studies with outcome blood pressure (details are provided in appendix 7). One paper, a cross-sectional study graded $\mathrm{B}$, was chosen in the systematic review process to be evaluated for the evidence of an association between protein intake and blood pressure.

Cross sectional study

Ulbak et al. (58) graded B, investigated in a cross sectional part of a randomized trial if macronutrients affected blood pressure in 2.5-year-old Danish children. The randomized trial concerned intake of n-3 long chain fatty acids of the mothers while lactating. Mothers kept 7 -days food registration when the children were 2.5 years, the age when blood pressure was measured. Measurement errors in the dietary recordings were not considered. $\mathrm{E} \%$ protein was significantly associated with both systolic and diastolic blood pressure, and g protein/day also significantly associated negatively with systolic blood pressure. The authors concluded that higher protein intake at the age of 2.5 years is associated with lower blood pressure.

\section{Conclusion}

Based on the low number of studies, we conclude that evidence is limited-inconclusive (grade 4) that higher protein intake is associated with decreased systolic blood pressure in young children.

\section{Neurodevelopment}

Table 8 shows a summary of studies with outcome neurodevelopment (details are provided in appendix 8). Two papers, both prospective cohort studies graded B, were chosen in the systematic review process to be evaluated for the evidence of an association between protein intake and neurodevelopment.

Prospective cohort studies

Morgan et al. (37) graded B, studied health outcomes from complementary foods, especially growth and neurocognitive outcome from meat consumption and breastfeeding. Neurocognitive outcome was determined from the mental and psychomotor scales of the Bayley Scales of Infant Development II at the age of 22 months. Red and white meat consumption was calculated from 7-days' weighed food intake diaries kept regularly at 4-month intervals from 4 months of age to 24 months. Measurement errors in the dietary recordings were not considered. 
Total meat intake from all registrations at 4-12 months, that is, three times the 7-days' registration $(p<0.02)$ as well as $4-16$ months (four registrations) $(p<0.013)$ were positively and significantly related to psychomotor developmental indices. The authors concluded that meat intake from 4 to 16 months was associated with psychomotor development (and increased weight gain) possibly via its protein content. (Note: can the effect of 'larger child eating more' be excluded? Larger children, in this population from birth weight $2500 \mathrm{~g}$, are likely to be more developed.)

Rask-Nissilä et al. (59) graded B, tested in 496 children, participating in the prospective STRIP project (the Special Turku Coronary Risk Factor Intervention Study), if dietary and other factors were associated with neurodevelopment. Neurodevelopment was tested at the age of 5 years by using a collection of developmental screening tests. Dietary intake was tested at 8,13 , and 18 months of age and thereafter twice a year. Measurement errors in the dietary recordings were not considered. In boys, stepwise logistic regression showed that protein intake predicted by positive association the outcome in speech and language skill tests at the age of 5 years.

\section{Conclusion}

Based on the low number of studies, we conclude that evidence is limited-inconclusive (grade 4) that higher protein intake is associated with improved neurodevelopment in children.

\section{Discussion}

The overall aim of this SLR was to evaluate recent scientific data on the short- and long-term health effects of different levels of protein intake in infancy and childhood, in order to appraise the current Nordic recommendations, NNR4 (25).

Research questions were developed involving six main outcomes and studies related to these have been presented in this review. A summary of the grading of the evidence for the various outcomes is presented in Table 9. It should be emphasized that the grading of evidence is only based on studies published between January 2000 and December 2011.

We found the evidence convincing (grade 1) that higher protein intake in infancy and early childhood is associated with increased growth and higher BMI in childhood. Which age period is most sensitive to high protein intake is not clear, but with regard to available data the first 2 years of life seems probable. Due to a scarcity of strong studies there is also limited-inconclusive evidence (grade 4) that protein intake in later childhood is associated with later BMI. There is limited-suggestive evidence (grade 3) that intake of animal protein, especially from dairy, have a stronger positive association with growth than vegetable protein has. The association found between higher intake of milk and increased levels of sIGF-I strengthens this.

There is limited-inconclusive evidence (grade 4) that protein intake is related to timing of AR. The evidence is also limited-inconclusive (grade 4) (due to the two Agraded studies not being independent) that there is an association between higher protein intake in early childhood and later body fat increases. There might also be different effects depending on BMI, phenotypes and gender.

We conclude that evidence is limited but suggestive (grade 3) for a positive association between total protein intake and BMC and/or other bone variables in childhood and adolescence.

Based on the fact that three of the papers of the original search came from the same group, we first concluded that evidence was slightly too weak to grade it as probable that increased intake of animal protein in childhood is related to earlier puberty, but as the paper found in the complementary search support this conclusion, we judge that the evidence grade increases to probable (grade 2).

Regarding other outcomes, this SLR considers that the number of published studies is far too few to enable any conclusions and more research is needed. Evidence is limited-inconclusive (grade 4) that milk protein fractions are related to glucose-insulin metabolism in infancy and childhood. The same level of evidence (grade 4) was found for an association between higher protein intake and decreased blood pressure, as well as for improved neurodevelopment in children.

\section{Protein intake in infancy and young childhood}

Food and nutrient intake during the complementary feeding period, that is, the transition period from milk feeding (breast milk and/or formula) to family foods and its importance for later health has been discussed but not so much studied. Advice given to parents has been and still is more based on custom than scientific evidence.

One major concern during the last decades has been the increasing prevalence of overweight and obesity among both children and adults around the globe. High protein intake during early childhood has been discussed as a possible contributing factor, and Agostoni et al. (60) suggest an increased risk for early AR and later overweight if more than $14 \mathrm{E} \%$ comes from proteins in the 6-24 months period.

The protein intake in the RCT-study by Koletzko et al. (29) corresponded at 12 months to $14.0 \mathrm{E} \%$ in the lowprotein formula group and $16.7 \mathrm{E} \%$ in the high-protein formula group (calculated from fig. 2 in the paper), with the higher intake in the latter group associated with increased risk for overweight at 24 months. Scaglione et al. (38) found that 5 year old overweight children had a 
Table 9. Grading of evidence for health effects associated with protein intake in infancy and childhood in industrialized countries based on an SLR including 34 papers graded A or B and four additional papers graded B from the complementary search

\begin{tabular}{|c|c|c|}
\hline Outcome & Evidence grading & $\begin{array}{c}\text { Reference number' } \\
\text { (quality grading) }\end{array}$ \\
\hline \multirow[t]{23}{*}{ BMI/growth } & Convincing evidence (grade I) that higher protein intake & $3(B)^{2,3}$ \\
\hline & in infancy and early childhood is associated with increased & $4(B)^{2}$ \\
\hline & growth and/or higher BMI in childhood. & $5(B)^{4}$ \\
\hline & & $13(B)^{2,5}$ \\
\hline & & $29(A)^{2}$ \\
\hline & & $30(B)^{4}$ \\
\hline & & $34(\mathrm{~A})^{2}$ \\
\hline & & $35(A)^{2,5}$ \\
\hline & & $36(B)^{2}$ \\
\hline & & $37(B)^{2,5}$ \\
\hline & & $38(B)^{2}$ \\
\hline & & $39(\mathrm{~B})^{2}$ \\
\hline & & $42(B)^{2}$ \\
\hline & & $44(B)^{2}$ \\
\hline & Limited-suggestive evidence (grade 3) that intake of animal protein, especially from dairy, have a stronger & $\begin{array}{l}45(B)^{4,6} \\
13(B)^{2,5}\end{array}$ \\
\hline & association with growth than vegetable protein has. The association found between higher intake of milk and & $31(B)^{2,5}$ \\
\hline & increased levels of IGF-I strengthens this & $35(A)^{2,5}$ \\
\hline & & $37(B)^{2,5}$ \\
\hline & Limited-inconclusive evidence (grade 4) that higher protein intake in later childhood is associated with & $4(B)^{2}$ \\
\hline & higher BMI in childhood & $39(B)^{2}$ \\
\hline & & $40(B)^{3,4}$ \\
\hline & & $42(B)^{2}$ \\
\hline & & $43(B)^{3}$ \\
\hline \multirow{6}{*}{$\begin{array}{l}\text { Body } \\
\text { composition }\end{array}$} & Limited-inconclusive evidence (grade 4) that protein intake is related to timing of adiposity & $\begin{array}{l}44(B)^{2} \\
32(B)^{4}\end{array}$ \\
\hline & rebound $(A R)$ & $33(B)^{3,4}$ \\
\hline & Limited-inconclusive evidence (grade 4) that there is an association between higher protein intake in early & $34(A)^{2}$ \\
\hline & childhood and later body fat increases (due to the two A-graded studies not being independent and studies & $35(\mathrm{~A})^{2}$ \\
\hline & from different groups finding opposing associations). & $40(B)^{3,5,7}$ \\
\hline & & $4 \mathrm{I}(\mathrm{B})^{3,5}$ \\
\hline \multirow[t]{5}{*}{ sIGF-I } & Limited-suggestive evidence (grade 3 ) that intake of animal protein, especially from dairy, have a stronger & $\begin{array}{l}42(B)^{2,4} \\
13(B)^{2}\end{array}$ \\
\hline & association with growth than vegetable protein has. The association found between higher intake of milk and & $14(B)^{7}$ \\
\hline & increased levels of IGF-I strengthens this. & $27(B)^{2}$ \\
\hline & & $28(B)^{2}$ \\
\hline & & $30(B)^{2}$ \\
\hline \multirow[t]{8}{*}{ Bone } & Limited-suggestive evidence (grade 3 ) for a positive association between total protein intake and bone & $\begin{array}{l}45(B)^{2,6} \\
14(B)^{5}\end{array}$ \\
\hline & mineral content (BMC) and/or other bone variables in childhood and adolescence. & $46(B)^{5}$ \\
\hline & & $47(B)^{2}$ \\
\hline & & $48(B)^{2,3}$ \\
\hline & & $49(B)^{2,5}$ \\
\hline & & $50(B)^{2}$ \\
\hline & & $51(B)^{4,6}$ \\
\hline & Probable evidence (grade 2) that increased intake of animal protein in childhood is related to earlier & $\begin{array}{l}52(B)^{6,7} \\
53(B)^{2,5}\end{array}$ \\
\hline \multirow{4}{*}{ Puberty } & puberty (final decision reached after the current systematic literature review was supported by a recent & $54(\mathrm{~A})^{2,5}$ \\
\hline & paper found by the complementary search.) & $55(B)^{2,5}$ \\
\hline & & $56(B)^{2,5}$ \\
\hline & & $57(\mathrm{~B})^{2,5,6}$ \\
\hline
\end{tabular}




\begin{tabular}{|c|c|c|}
\hline Outcome & Evidence grading & $\begin{array}{c}\text { Reference number' } \\
\text { (quality grading) }\end{array}$ \\
\hline $\begin{array}{c}\text { Glucose-insulin } \\
\text { metabolism }\end{array}$ & $\begin{array}{l}\text { Limited-inconclusive evidence (grade 4) that milk protein fractions are related to glucose-insulin } \\
\text { metabolism in infancy and childhood. }\end{array}$ & $\begin{array}{l}27(B)^{2,5} \\
31(B)^{2,5}\end{array}$ \\
\hline Blood pressure & $\begin{array}{l}\text { Limited-inconclusive evidence (grade } 4 \text { ) that protein intake is associated with blood pressure in small } \\
\text { children. }\end{array}$ & $58(B)^{7}$ \\
\hline $\begin{array}{l}\text { Neuro-develop- } \\
\text { ment }\end{array}$ & $\begin{array}{l}\text { Limited-inconclusive evidence (grade 4) that protein intake is associated with neurodevelopment in } \\
\text { children }\end{array}$ & $\begin{array}{l}37(B)^{2,5} \\
59(B)^{2}\end{array}$ \\
\hline
\end{tabular}

'Bold font indicates clinical trials; plain text indicates cohort studies; italics indicate cross-sectional studies.

${ }^{2}$ Positive associations found with protein intake

${ }^{3}$ Gender seem to affect the associations

${ }^{4}$ No significant associations found with protein intake

${ }^{5}$ Associations depending on protein source or amino acid studied

${ }^{6}$ From the complementary search (i.e. not to be found in summary tables or appendices)

${ }^{7}$ Negative associations found with protein intake

higher percentage intake of proteins at the age of 1 year than non-overweight children ( $22 \mathrm{E}$ vs. $20 \mathrm{E} \%$ ).

To provide advice to health care providers and regulatory bodies, the European Society for Paediatric Gastroenterology, Hepatology and Nutrition (ESPGHAN) published in 2008 a comment on complementary feeding where they stated that Despite theoretical concerns about the potential effects of different aspects of complementary feeding on later obesity risk, the available evidence is not persuasive (61). However, several papers of good quality have been published since then and the present SLR supports the conclusion in the paper by Agostoni et al (60).

It can be seen from the studies published on protein intake in the latter half of the first year that there is increased growth and increased risk of overweight later in childhood when the $\mathrm{E} \%$ from protein at 12 months of age is between 15 and $20 \mathrm{E} \%$. We therefore suggest a mean intake of $15 \mathrm{E} \%$ as upper limit at 12 months as there is no risk of too low protein intake at this level but might be increased risk of later overweight with higher intake. This level $(15 \mathrm{E} \%)$ would also be comparable to the protein content of an average diet among children in the Nordic countries during the first few years (Table 1).

The present SLR focuses on the protein intake in young childhood. The literature is so very scarce on protein intake in older children and adulthood vs. BMI development that it could not be treated in an SLR. Results from some studies on weight loss programs for adults have suggested that a high protein intake can result in more weight loss, but this question is not treated in this SLR.

\section{Milk and protein intake in a Nordic setting}

The intake of protein among children in the Nordic countries is $2-3$ times higher than physiological require- ments (Table 1). One source of protein is milk and milk products, which are often consumed in large amounts in the Nordic countries. The latest Swedish national study (23) on intake among 4-, 7- and 11-year olds show that at least $25 \%$ of all age groups consume more than $500 \mathrm{ml}$ of milk, fermented milk and yoghurt per day, and 5\% of boys aged 7 and 11 years consume at least $1 \mathrm{~L} /$ day. The reported intake of meat was also large with a median intake of 63, 98 and $98 \mathrm{~g} /$ day in the respective age groups. Five percent of 4-year olds reported a meat intake over $150 \mathrm{~g} / \mathrm{day}$, and $5 \%$ of 7 - and 11- year olds reported eating more than $200 \mathrm{~g} /$ day. With regard to the results of the present SLR, it seems prudent to advise against too high an intake of protein rich foods, for example, cow's milk, during the first years of childhood.

\section{Methodological concerns}

A difficulty with studies on the effect of protein intake is to ascertain whether any effects are mainly due to protein as such, or to other properties of the protein source (e.g. in dairy products the effects could be due to specific amino acid patterns, peptides, growth factors, minerals or a combination of these). Many studies included in the present SLR do not make this differentiation.

There are conflicting results about the relationship between milk and/or dairy intake and adiposity and body composition in children; some studies show a protective effect while others show negative or no effects (62). There are several possible reasons for this, including differences in methodology both with regard to anthropometric measurements and dietary intake. With regard to the results of the present SLR, we would suggest that it is also important to adjust for the protein intake during the first $1-2$ years.

Another important factor is whether individuals with implausible dietary recordings are included or not. 
Well-performed prospective studies with well-defined and validated dietary assessment methods are needed in all studies aiming to evaluate associations between dietary intake and health outcomes. Many studies included in the present SLR have not considered the validity of the reported dietary intake, which could be problematic. However, protein intake seems to be less affected by faulty reporting than many other nutrients and it is very unlikely that this would cause the associations between reported protein intake and health outcomes found in the present SLR to be inaccurate.

Nordic collaboration with data from prospective longitudinal infant cohorts would be valuable with good possibilities of methodologically strong studies.

\section{Conclusions}

A high intake of protein in infancy and young childhood thus seems to be less than optimal, and associated with increased risk of obesity later in life. The intake of protein in the Nordic countries is, as in many industrialized countries, more than sufficient to meet physiological requirements among children and adults. However, the upper level of a healthy intake is yet to be firmly established. In the meantime, we suggest a mean intake of $15 \mathrm{E} \%$ as the upper limit at 12 months as there is no risk of too low protein intake at this level but might be increased risk of later overweight with higher intake. One way to decrease protein intake would be to promote breastfeeding throughout the first year of life or as long as it suits the mother and child, and to avoid too high intakes of protein rich foods, for example, cow's milk.

\section{Acknowledgements}

Special thanks to Hege Sletsjøe, Jannes Engquist, Mikaela Bachmann, Ulla-Kaisa Koivisto Hursti, and Wulf Becker for their help and guidance throughout the whole process.

\section{Conflict of interest and funding}

None of the authors had any conflict of interest. The Nordic Council of Ministers supported the work.

\section{Contributions of authors}

Agneta Hörnell was the leading author. All four coauthors worked equally on the literature review, grading of evidence, drawing conclusions, and writing of the paper.

\section{References}

1. Michaelsen KF, Larnkjær A, Mølgaard C. Amount and quality of dietary proteins during the first two years of life in relation to NCD risk in adulthood. Nutr Metab Cardiovasc Dis 2012 Oct; 22: 781-6. doi: 10.1016/j.numecd.2012.03.014

2. Rolland-Cachera MF, Deheeger M, Akrout M, Bellisle F. Influence of macronutrients on adiposity development: a follow up study of nutrition and growth from 10 months to 8 years of age. Int J Obes Rel Metabol Dis 1995; 19: 573-8.

3. Gunnarsdottir I, Thorsdottir I. Relationship between growth and feeding in infancy and body mass index at the age of 6 years. Int J Obes Rel Metabol Dis 2003; 27: 1523-7.

4. Öhlund I, Hernell O, Hörnell A, Stenlund H, Lind T. BMI at 4 years of age is associated with previous and current protein intake and with paternal BMI. Eur J Clin Nutr 2010; 64: 138-45.

5. Räihä NC, Fazzolari-Nesci A, Cajozzo C, Puccio G, Monestier A, Moro G, et al. Whey predominant, whey modified infant formula with protein/energy ratio of $1.8 \mathrm{~g} / 100 \mathrm{kcal}$ : adequate and safe for term infants from birth to four months. J Pediatric Gastroenterol Nutr 2002; 35: 275-81.

6. Michaelsen KF. Are there negative effects of an excessive protein intake? Pediatrics 2000; 106: 1293.

7. Baird J, Fisher D, Lucas P, Kleijnen J, Roberts H, Law C. Being big or growing fast: systematic review of size and growth in infancy and later obesity. BMJ 2005; 331: 929.

8. Monteiro PO, Victora CG. Rapid growth in infancy and childhood and obesity in later life - a systematic review. Obes Rev 2005; 6: 143-54.

9. Ong KK, Loos RJ. Rapid infancy weight gain and subsequent obesity: systematic reviews and hopeful suggestions. Acta Paediatr 2006; 95: 904-8.

10. Atladottir H, Thorsdottir I. Energy intake and growth of infants in Iceland - a population with high frequency of breast-feeding and high birth weight. Eur J Clin Nutr 2000; 54: 695-701.

11. Dewey KG. Growth characteristics of breast-fed compared to formula-fed infants. Biol Neonate 1998; 74: 94-105.

12. Koletzko B, Broekaert I, Demmelmair H, Franke J, Hannibal I, Oberle D, et al. Protein intake in the first year of life: a risk factor for later obesity? The E.U. childhood obesity project. Adv Exp Med Biol 2005; 569: 69-79.

13. Hoppe C, Udam TR, Lauritzen L, Molgaard C, Juul A, Michaelsen KF. Animal protein intake, serum insulin-like growth factor I, and growth in healthy 2.5-y-old Danish children. Am J Clin Nutr 2004; 80: 447-52.

14. Budek AZ, Hoppe C, Michaelsen KF, Bügel S, Mølgaard C. Associations of total, dairy, and meat protein with markers for bone turnover in healthy, prepubertal boys. J Nutr 2007; 137: 930-4.

15. Niinikoski H, Pahkala K, Ala-Korpela M, Viikari J, Rönnemaa $\mathrm{T}$, Lagström $\mathrm{H}$, et al. Effect of repeated dietary counseling on serum lipoproteins from infancy to adulthood. Pediatrics 2012; 129: e704-13.

16. Talvia $S$, Lagström $H$, Räsänen $M$, Salminen $M$, Räsänen $L$, Salo $\mathrm{P}$, et al. A randomized intervention since infancy to reduce intake of saturated fat: calorie (energy) and nutrient intakes up to the age of 10 years in the Special Turku Coronary Risk Factor Intervention Project. Arch Pediatr Adolesc Med 2004; 158: 41-7.

17. Thorsdottir I, Thorisdottir A, Palsson G. The diet of Icelandic infants - results from a research on infant's diet, growth and iron status 2005-2007 (Mataræði íslenskra ungbarna - Niðurstöður rannsóknar á mataræði, vexti og járnbúskap ungbarna 20052007). Reykjavik: Unit for Nutrition Research; 2008.

18. Gunnarsdottir I, Helgadottir H, Thorisdottir B, Thorsdottir I. Diet of six-year-old Icelandic infants - National dietary survey 2011-2012 (In Icelandic: Landskönnun á mataræði sex ára barna 2011-2012). Icelandic Medical Journal [Internet]. 20136 March 2013. http://www.laeknabladid.is/tolublod/2013/01/nr/ 4734.

19. Øverby NC, Kristiansen AL, Andersen LF, Lande B. Spedkost 12 måneder - landsomfattende kostholdsunders $\varnothing$ kelse blant 12 måneder gamle barn (In Norwegian). Oslo: Norwegian Directorate of Health; 2009 (IS-1635). http://www.helsedirektora- 
tet.no/folkehelse/ernering/tall-og-undersokelser/spedbarn/Sider/ 12-maneder-gamle-barn.aspx

20. Kristiansen AL, Andersen LF, Lande B. Småbarnskost 2007 landsomfattende kostholdsundersøkelse blant 2 år gamle barn (in Norwegian). Oslo: Norwegian Directorate of Health, 2009 (IS-1731). http://www.helsedirektoratet.no/folkehelse/ernering/ tall-og-undersokelser/barn-og-ungdom/Sider/smabarnskost-2aringer.aspx

21. Pollestad ML, Øverby NC, Andersen LF. Kosthold blant 4åringer. Landsomfattende kostholdsundersøkelse - UNGKOST 2000 (In Norwegian). Oslo: Norwegian Directorate for Health and Social Affairs; 2002 (IS-1067). http://www.helsedirektoratet.no/folkehelse/ernering/tall-og-undersokelser/barn-og-ung$\mathrm{dom} /$ Sider/kosthold-4-aringer.aspx

22. Øverby NC, Andersen LF. Landsomfattende kostholdsundersøkelse blant elever i 4.- og 8. klasse i Norge - UNGKOST 2000 (In Norwegian). Oslo: Norwegian Directorate for Health and Social Affairs; 2002 (IS-1019). http://www.helsedirektoratet.no/ folkehelse/ernering/tall-og-undersokelser/barn-og-ungdom/ Sider/storre-barns-kosthold.aspx

23. Enghardt Barbieri H, Pearson M, Becker W. Riksmaten - barn 2003. Uppsala: Livsmedelsverket; 2003.

24. $\mathrm{FAO} / \mathrm{WHO} / \mathrm{UNU}$. Protein and amino acid requirements in human nutrition. Joint WHO/FAO/UNU Expert Consultation. World Health Organ Tech Rep Ser 2007; 1-265.

25. Nordic Council of Ministers. Nordic Nutrition Recommendations 2004. Integrating nutrition and physical activity. 2005.

26. NNR5 working group. A guide for conducting systematic literature reviews for the 5th edition of the Nordic Nutrition recommendations Copenhagen: Nordic Council of Ministers; 2011 [updated Revised version 2011-06-08; cited 20 Feb 2013]. http://www.slv.se/upload/NNR5/A \%20guide $\% 20$ for $\% 20$ conducting $\% 20$ SLR $\% 20$ for $\% 20$ NNR5\%20FINAL.pdf.

27. Hoppe C, Mølgaard C, Dalum C, Vaag A, Michaelsen KF. Differential effects of casein versus whey on fasting plasma levels of insulin, IGF-1 and IGF-1/IGFBP-3: results from a randomized 7-day supplementation study in prepubertal boys. Eur J Clin Nutr 2009; 63: 1076-83.

28. Hoppe C, Mølgaard C, Juul A, Michaelsen KF. High intakes of skimmed milk, but not meat, increase serum IGF-I and IGFBP3 in eight-year-old boys. Eur J Clin Nutr 2004; 58: 1211-6.

29. Koletzko B, von Kries R, Closa R, Escribano J, Scaglioni S, Giovannini $\mathrm{M}$, et al. Lower protein in infant formula is associated with lower weight up to age 2 y: a randomized clinical trial. Am J Clin Nutr 2009; 89: 1836-45.

30. Larnkjaer A, Hoppe C, Mølgaard C, Michaelsen KF. The effects of whole milk and infant formula on growth and IGF-I in late infancy. Eur J Clin Nutr 2009; 63: 956-63.

31. Sandström O, Lönnerdal B, Graverholt G, Hernell O. Effects of alpha-lactalbumin-enriched formula containing different concentrations of glycomacropeptide on infant nutrition. Am J Clin Nutr 2008; 87: 921-8.

32. Dorosty AR, Emmett PM, Cowin S, Reilly JJ. Factors associated with early adiposity rebound. ALSPAC Study Team. Pediatrics 2000; 105: 1115-8.

33. Günther AL, Buyken AE, Kroke A. The influence of habitual protein intake in early childhood on BMI and age at adiposity rebound: results from the DONALD Study. Int J Obes 2006; 30: $1072-9$.

34. Günther AL, Buyken AE, Kroke A. Protein intake during the period of complementary feeding and early childhood and the association with body mass index and percentage body fat at $7 \mathrm{y}$ of age. Am J Clin Nutr 2007; 85: 1626-33.

35. Günther AL, Remer T, Kroke A, Buyken AE. Early protein intake and later obesity risk: which protein sources at which time points throughout infancy and childhood are important for body mass index and body fat percentage at $7 \mathrm{y}$ of age? Am J Clin Nutr 2007; 86: 1765-72.

36. Hoppe C, Molgaard C, Thomsen BL, Juul A, Michaelsen KF. Protein intake at 9 mo of age is associated with body size but not with body fat in 10-y-old Danish children. Am J Clin Nutr 2004; 79: 494-501.

37. Morgan J, Taylor A, Fewtrell M. Meat consumption is positively associated with psychomotor outcome in children up to 24 months of age. J Pediatr Gastroenterol Nutr 2004; 39: 493-8.

38. Scaglioni S, Agostoni C, Notaris RD, Radaelli G, Radice N, Valenti M, et al. Early macronutrient intake and overweight at five years of age. Int J Obes Relat Metab Disord 2000; 24: 777-81.

39. Skinner JD, Bounds W, Carruth BR, Morris M, Ziegler P. Predictors of children's body mass index: a longitudinal study of diet and growth in children aged 2-8 y. Int J Obes Relat Metab Disord 2004; 28: 476-82.

40. van Vught AJ, Heitmann BL, Nieuwenhuizen AG, Veldhorst MA, Brummer RJ, Westerterp-Plantenga MS. Association between dietary protein and change in body composition among children (EYHS). Clin Nutr 2009; 28: 684-8.

41. van Vught AJ, Heitmann BL, Nieuwenhuizen AG, Veldhorst MA, Andersen LB, Hasselstrom H, et al. Association between intake of dietary protein and 3-year-change in body growth among normal and overweight 6-year-old boys and girls (CoSCIS). Public Health Nutr 2010; 13: 647-53.

42. Kourlaba G, Pitsiladis YP, Lagou V, Grammatikaki E, Moran $\mathrm{CN}$, Kondaki K, et al. Interaction effects between total energy and macronutrient intakes and angiotensin-converting enzyme 1 (ACE) I/D polymorphism on adiposity-related phenotypes in toddlers and preschoolers: the growth, exercise and nutrition pidemiological study in preschoolers: the GENESIS study. [corrected]. Br J Nutr 2008; 100: 1333-40.

43. Maillard G, Charles MA, Lafay L, Thibult N, Vray M, Borys JM, et al. Macronutrient energy intake and adiposity in nonobese prepubertal children aged 5-11 y (the Fleurbaix Laventie Ville Santé Study). Int J Obes Relat Metab Disord 2000; 24: 1608-17.

44. Manios Y, Grammatikaki E, Papoutsou S, Liarigkovinos T, Kondaki K, Moschonis G. Nutrient intakes of toddlers and preschoolers in Greece: the GENESIS study. J Am Diet Assoc 2008; 108: 357-61.

45. Closa-Monasterolo R, Ferré N, Luque V, Zaragoza-Jordana M, Grote V, Weber M, et al. Sex differences in the endocrine system in response to protein intake early in life. Am J Clin Nutr 2011; 94(6 Suppl): 1920S-7.

46. Budek AZ, Hoppe C, Michaelsen KF, Mølgaard C. High intake of milk, but not meat, decreases bone turnover in prepubertal boys after 7 days. Eur J Clin Nutr 2007; 61: 957-62.

47. Alexy U, Remer T, Manz F, Neu CM, Schoenau E. Long-term protein intake and dietary potential renal acid load are associated with bone modeling and remodeling at the proximal radius in healthy children. Am J Clin Nutr 2005; 82: 1107-14.

48. Bounds W, Skinner J, Carruth BR, Ziegler P. The relationship of dietary and lifestyle factors to bone mineral indexes in children. J Am Diet Assoc 2005; 105: 735-41.

49. Budek AZ, Hoppe C, Ingstrup H, Michaelsen KF, Bügel S, Mølgaard C. Dietary protein intake and bone mineral content in adolescents-The Copenhagen Cohort Study. Osteoporos Int 2007; 18: 1661-7.

50. Hoppe C, Molgaard C, Michaelsen KF. Bone size and bone mass in 10-year-old Danish children: effect of current diet. Osteoporos Int 2000; 11: 1024-30.

51. Libuda L, Wudy SA, Schoenau E, Remer T. Comparison of the effects of dietary protein, androstenediol and forearm muscle 
area on radial bone variables in healthy prepubertal children. $\mathrm{Br}$ J Nutr 2011; 105: 428-35.

52. Mark AB, Hoppe C, Michaelsen KF, Mølgaard C. Milk-derived proteins and minerals alter serum osteocalcin in prepubertal boys after 7 days. Nutr Res 2010; 30: 558-64.

53. Berkey CS, Gardner JD, Frazier AL, Colditz GA. Relation of childhood diet and body size to menarche and adolescent growth in girls. Am J Epidemiol 2000; 152: 446-52.

54. Günther AL, Karaolis-Danckert N, Kroke A, Remer T, Buyken AE. Dietary protein intake throughout childhood is associated with the timing of puberty. J Nutr 2010; 140: 565-71.

55. Remer T, Shi L, Buyken AE, Maser-Gluth C, Hartmann MF, Wudy SA. Prepubertal adrenarchal androgens and animal protein intake independently and differentially influence pubertal timing. J Clin Endocrinol Metab 2010; 95: 3002-9.

56. Shi L, Wudy SA, Buyken AE, Hartmann MF, Remer $T$. Body fat and animal protein intakes are associated with adrenal androgen secretion in children. Am J Clin Nutr 2009; 90: $1321-8$.

57. Rogers IS, Northstone K, Dunger DB, Cooper AR, Ness AR, Emmett PM. Diet throughout childhood and age at menarche in a contemporary cohort of British girls. Public Health Nutr 2010; 13: 2052-63.
58. Ulbak J, Lauritzen L, Hansen HS, Michaelsen KF. Diet and blood pressure in 2.5-y-old Danish children. Am J Clin Nutr 2004; 79: 1095-102.

59. Rask-Nissilä L, Jokinen E, Terho P, Tammi A, Hakanen M, Rönnemaa T, et al. Effects of diet on the neurologic development of children at 5 years of age: the STRIP project. J Pediatr 2002; 140: 328-33.

60. Agostoni C, Scaglioni S, Ghisleni D, Verduci E, Giovannini M, Riva E. How much protein is safe? Int J Obes 2005; 29(Suppl 2): S8-13.

61. Agostoni C, Decsi T, Fewtrell M, Goulet O, Kolacek S, Koletzko B, et al. Complementary feeding: a commentary by the ESPGHAN Committee on Nutrition. J Pediatr Gastroenterol Nutr 2008; 46: 99-110.

62. Noel SE, Ness AR, Northstone K, Emmett P, Newby PK. Milk intakes are not associated with percent body fat in children from ages 10 to 13 years. J Nutr 2011; 141: 2035-41.

\footnotetext{
*Agneta Hörnell

Department of Food and Nutrition

Umeå University

SE-90I 87 Umeå, Sweden

Email: Agneta.hornell@kost.umu.se
} 